\title{
China and International Housing Price Growth*
}

\author{
Yuk Ying Chang ${ }^{\mathrm{a}}{ }^{\dagger}$, Hamish Anderson ${ }^{\mathrm{a}}$, and Song Shi ${ }^{\mathrm{b}}$
}

\begin{abstract}
We document the Chinese effects on international residential property price growth. We show faster growth of the housing prices associated with larger decline in recent past growth of China's GDP, larger increases in China's savings rate, or stronger rise in China's risks. These results are consistent with the notion of Chinese investing in overseas property markets when faced with less promising investment opportunities at home and when they have the means to invest offshore. These effects are stronger for countries where English is the primary spoken language, with better tertiary education quality, and that exhibit lower correlations between local property market price growth and China's interest rate.
\end{abstract}

Keywords: international housing prices, China, overseas opportunities, investible funds, risk, English, education

JEL Codes: G11; R20; F21

\footnotetext{
* We acknowledge Sudipto Dasgupta for suggestions. We also thank Faruk Bali, Jie Gan, Adrian Lee, Richard Taffler, John Wei, Taojun Xie and Chu Zhang for comments and the participants at the 2017 American Real Estate and Urban Economics Association (AREUEA) International Conference and the 2017 European FMA Symposium. We thank Massey University's Business Impactful Research Fund for funding. We acknowledge Andrea Bennett for proofreading.

a School of Economics and Finance, Massey University, New Zealand.

${ }^{b}$ Faculty of Design, Architecture and Building, University of Technology Sydney, Australia.

+ Corresponding Author: Yuk Ying Chang. School of Economics and Finance, Massey University (Manawatu Campus), Private Bag 11-222, Palmerston North 4442, New Zealand; tel. +64-6-3569099 ext. 84073; email y.chang@massey.ac.nz.
} 


\section{China and International Housing Price Growth}

\section{Introduction}

Chinese investment in overseas property markets is widely covered in the media ${ }^{1}$ and draws attention from governments (e.g. the Australian, Canadian, and Singaporean governments have imposed restrictions on overseas property buyers). Anecdotal evidence suggests Chinese investment is significant ${ }^{2}$ and affects other countries' real estate markets, economies, and societies. It has been considered as a potential external source of turbulence (Reserve Bank of Australia 2016) as well as a stabiliser (Rapoza 2016 in Forbes). In 2015, the estimated global residential real estate value of US\$163 trillion is approximately double the world's gross domestic product (GDP) and comprises roughly $45 \%$ of mainstream global assets (Savills 2016). Therefore, even a relatively small Chinese impact on other countries' real estate would represent a very large change on global asset values (see also "Maple grief" 2017 in Economist).

Real estate studies typically focus on a single country (e.g. Lai et al. 2010; Mian et al. 2015), while multi-country studies primarily examine country-specific factors (e.g. Hott and Monnin 2008; Burnside et al. 2016), although general developments or global factors are also examined (e.g. Favilukis et al. 2013). However, to our knowledge, no internationally systematic study examining the Chinese impact has been undertaken. This motivates us to

\footnotetext{
${ }^{1}$ For example, Bloomberg (“China's army of global homebuyers Is suddenly short on cash", 27 January 2017), The Economist ("A roaring trade", 18 June 2016), Forbes ("The flipside of China's love for American real estate", 16 May 2016), The Wall Street Journal (“Chinese investors pour money Into U.S. property”, 25 May 2016), Reuters ("Why Chinese investment in overseas real estate has more than doubled", 18 August 2016), Financial Times ("Beijing clampdown slows China spending spree on US property", 16 May 2016), and Bloomberg ("Chinese buyers hungry for Canadian homes with inquiries up 134\%", 14 April 2016).

2 According to Juwai, a leading international real estate broker specializing in Chinese investors, Chinese spent US\$52 billion on foreign property in 2015, up from US\$10 billion three years ago. This amount is predicted to hit US\$220 billion by 2020 (see https://list.juwai.com).
} 
explore how China affects housing markets of other countries. In particular, we investigate (a) whether China affects international housing markets, (b) which countries are more strongly affected, (c) and what conditions influence the effects.

Based on quarterly data of 23 countries primarily from 1993-2015, we find the real residential housing price indices' growth is significantly negatively associated with the average growth of China's real GDP in the past four quarters. In addition, it is significantly positively associated with contemporaneous changes in China's savings rate (investible funds) in the same year after controlling for common real estate explanatory variables. On average, international housing prices increase approximately $0.23 \%$ following a $1 \%$ decrease in China's GDP growth. Further, a $1 \%$ increase in China's savings rate is associated with a $1 \%$ increase international housing prices on average. Given the massive global value of residential real estate (Savills 2016), even a $0.23 \%$ increase plausibly represents a very large impact on the local economy ${ }^{3}$. Further, it is economically significant as, on average, a $1 \%$ decrease in China's GDP growth has the equivalent housing price impact as a $0.89 \%$ increase in the local country's GDP.

The GDP growth of the United States, the United Kingdom, or the aggregate of France, Germany, and the United Kingdom does not have such pervasive effects as those of China's GDP growth. We obtain similar results when we replace China's GDP growth with interest rates or consumer confidence expectations and China's savings rate with wealth growth. These results are consistent with the notion of Chinese investing in overseas property markets when China has less promising domestic investment opportunities and they have the means (savings and wealth) to do so. These significant relations persist when recent economic

\footnotetext{
${ }^{3}$ In this paper, the term local refers to one of the 23 countries we examine.
} 
downturns are excluded or when separating the differential effect of the post-2007 period. We also obtain similar results when controlling for bubbles in China's stock and property markets. The relation with China's GDP is prevalent, but relatively stronger for residential property markets in the United States, the United Kingdom, Ireland, Australia, the Netherlands, France, Sweden, Luxembourg, South Korea, and South Africa.

Concerning the conditions under which these relations are stronger, we obtain the following findings. First, the relations are more pronounced when economic risk is higher in China or when the media covers more Chinese risk/uncertainty stories. Second, the investible funds effect is more pronounced in local property markets with a lower correlation with China's interest rate. Third, the relations are stronger for housing markets located in Englishspeaking countries. Finally, there are more apparent Chinese effects in countries with quality tertiary education and local country real estate prices grow faster for China's top destinations for tertiary student migration when China is politically riskier.

We search major policy changes for international property buyers or key rule changes that affect the ease of Chinese capital outflows. We find that corresponding residential housing prices grow faster following a relaxation of capital outflows for Chinese resident from China in 2007 and a relaxation for foreigners to purchase properties in Australia in December 2008. We also find that related housing prices grow slower following an imposition of a capital gains tax for overseas investors buying UK residential property in April 2015 and a restriction for foreigners buying properties in Australia in April 2010. However, as there are few major exogenous shocks to exploit for robustness analyses we are strongly cautious and conservative about generalisation of the results. ${ }^{4}$

\footnotetext{
${ }^{4}$ We have not considered the impact of China's capital outflow control rule implemented in January 2017 due to insufficient post-event observations. However, anecdotal evidence in countries including Australia, Canada
} 
Our work is related to two strands of research. First, we add to the literature on the effects of external factors on local property markets. Previous studies have examined immigration (e.g. Saiz 2003), exchange rates (e.g. Rodríguez and Bustillo 2010), foreign capital flows (e.g. Aizenman and Jinjarak 2009), foreign direct investment (e.g. Farrell 1997), and tourism (e.g. Rodríguez and Bustillo 2010) on local property prices. However, our study examines the impacts of investment opportunities, investible funds and the risks of a single country, China, on international housing markets.

Second, we follow the mainstream finance literature in examining factors affecting Chinese overseas property investment. In the Markowitz (1952) portfolio selection model, risk, returns, and correlations ${ }^{5}$ (for diversification) are the major determinants of an optimal portfolio. Numerous studies consider these determinants, including housing risk (e.g. Yao and Zhang 2005), housing returns (e.g. Meyer and Wieand 1996), and whether housing risk can be diversified (e.g. Cotter et al. 2015). The literature also suggests investors prefer politically stable environments (e.g. La Porta et al. 1997). In addition, studies find people are inclined to invest in assets for which they have more information and with which they are more familiar (e.g. Coval and Moskowitz 1999; Grinblatt and Keloharju 2001; Huberman 2001; Ivkovíc and Weisbenner 2005; Massa and Simonov 2006). Economists have also long recognized the importance of information about products on consumer behaviour (Nelson 1970). ${ }^{6}$ In this

\footnotetext{
and New Zealand suggests this exogenous event restricting domestic Chinese investible funds outside of China has significantly negatively impacted international property markets. For example: Forbes ("Chinese overseas real estate buying spree slows, delayed by tightened capital controls" 31 July 2017), Reuters ("China's overseas property purchases, investments slump as capital controls bite" 16 February 2017).

${ }^{5}$ While people may not actually make complex calculations related to theories (i.e. portfolio theory), they act as if they do (McEachern 2011). Markowitz (1999) argues that investment diversification was well established in practice long before his seminal work in 1952 and highlights this by quoting from Act 1, Scene 1 of the Merchant of Venice -as evidence that Shakespeare was not only conversant with diversification but also intuitively understood covariance.

6 Properties are also consumption products and property buyers are therefore concerned about the environments associated with properties as well.
} 
study, we examine the above-mentioned factors. In addition, we study whether the attractive attributes of countries matter, including quality tertiary education. Real estate studies find premiums are paid for houses in areas with quality educational institutions such as schools (e.g. Figlio and Lucas 2004).

The remainder of this paper is organized as follows. Section 2 describes the data. Section 3 describes the methodology and states the hypotheses. Section 4 presents and discusses the empirical results. Section 5 concludes the paper.

\section{Data}

Our dependent variable is growth of housing price indices. The real seasonally adjusted quarterly housing price indices of 23 countries and their aggregate from 1975 Q1 to 2015 Q4 are obtained from Mack and Martínez-García (2011). The 23 countries are Australia, Belgium, Canada, Croatia, Denmark, Finland, France, Germany, Ireland, Israel, Italy, Japan, Luxembourg, the Netherlands, New Zealand, Norway, South Africa, South Korea, Spain, Sweden, Switzerland, the United Kingdom, and the United States. The indices are selected to be consistent with the US Federal Housing Finance Agency's quarterly nation wide house price index for single-family houses (formerly called the Office of Federal Housing Enterprise Oversight house price index). The same source also provides corresponding real seasonally adjusted quarterly personal disposable income series.

The sources of the key variables of interest are as follows: Datastream for China's quarterly real GDP growth since 1992, the prime lending rate, and consumer expectation; the World Bank for China's savings rate and annual GDP before 1992; Crédit Suisse (2015) for China's total wealth and wealth per adult; the PRS Group for China's political, economic, and financial risk ratings; Bloomberg for the numbers of China's risk stories and all stories; Solt 
(2016) for China's Gini coefficient; Wikipedia for the classification of English countries; Quacquarelli Symonds Limited for the QS higher education country ranking and the United Nations for the top five tertiary student migration destinations of China.

We obtain the raw data for the other control variables from the Economic Cycle Research Institute, Datastream, the PRS Group, Bloomberg, and the Organisation for Economic Co-operation and Development (OECD). We obtain international business cycle chronologies from the Economic Cycle Research Institute. Local and world GDP, unemployment rates, exchange rates, and consumer confidence indices are from Datastream. We obtain the political, economic and financial risk ratings of other countries from the PRS Group and local and global numbers of risk stories and all stories from Bloomberg. Finally, the OECD provides country-level household debt, short-term interest rates, rental price indices, production indices in construction, and indices of permits issued for dwellings or residential buildings. Where necessary, we convert all series into real seasonally adjusted quarterly series using the seasonality dummy approach. For daily or monthly series, we use the average of all days or months in a quarter. The variable definitions are given in the Appendix.

Table 1 shows the main variable summary statistics. Over the sample period from 1993 Q1 to 2015 Q4, China's real GDP growth is more than 10 times higher than for both local country and world real GDP growth. On the other hand, China's political risk is higher than that of the 23 other countries but comparable to the overall world political risk (where a lower rating indicates greater risk). China's economic risk is similar to our 23 local countries' economic risk average, while overall world economic risk is slightly higher. China's financial risk is also lower than its economic risk and local and world financial risk. 
Table 2 reports the correlation coefficients of the major variables. The relatively stronger correlation coefficients are mainly associated with certain risk variables. The world's risk story number is relatively strongly correlated with the world financial risk rating (0.557), China's political and financial risk ratings (-0.647 and 0.634, respectively), and China's and local proportions of stories about risk $^{7}$ ( 0.581 and 0.617 , respectively). China's financial risk rating is relatively strongly correlated with its economic risk rating (0.633), world financial risk rating $(0.726)$, and local risk story number $(0.567)$. Lastly, the world financial risk rating is relatively strongly correlated with the world economic risk rating $(0.512)$ and the local risk story number (0.502). Nevertheless, all variance inflation factors are well below 10 . Hence, multicollinearity is not a concern.

\section{Hypotheses and methodology}

The home bias literature shows that investors typically hold portfolios that are overweighted towards their home market, which suggests that the Chinese will invest mainly in Chinese-domiciled assets. However, certain factors may encourage the Chinese to invest offshore. In particular, in a spirit similar to the notion of 'push' and 'pull' factors in the capital flow literature (e.g. Calvo et al. 1993, 1996; Fernandez-Arias 1996; Chuhan et al. 1998; Fratzscher 2012), when there are fewer expected growth opportunities in China, the Chinese may seek offshore investment opportunities, including residential property. As motivation for overseas property investments, Newell and Worzala (1995) report that investors in a survey state 'lack of opportunities in domestic market' and 'higher returns than domestic markets' as key factors. Therefore, we predict that the Chinese will buy more overseas properties when

\footnotetext{
${ }^{7}$ We use "China" or "Chinese" as key words to obtain the total number of stories about China from Bloomberg. We add "risk" or "uncertainty" or "peril" as additional key words to obtain the total number of risk stories for China from Bloomberg. By the same method, we obtain the corresponding story counts for the world and other countries.
} 
expected growth opportunities in China are fewer, which would lead to faster real housing price growth (hpg) of overseas real estate markets. We call this the overseas opportunity hypothesis. To test this prediction, we empirically estimate the following model:

$$
h p g_{\mathrm{j}, \mathrm{t}}=\mathrm{a} 0+\mathrm{a} 1^{*} \text { China's expected growth opportunities } \mathrm{t}_{\mathrm{t}}+\text { Controls }_{\mathrm{j}, \mathrm{t}}+\mathrm{e}_{\mathrm{j}, \mathrm{t}}
$$

where the subscripts $\mathrm{j}$ and $\mathrm{t}$ index the country and quarter, respectively. We expect a1 to be negative. Lemmon and Portniaguina (2006) show that the GDP is fairly strongly associated with consumer confidence in expected macroeconomic conditions, a major determinant of growth opportunities. Therefore, we use the average of the real GDP growth of the past four quarters as a proxy for expected growth opportunities. In place of real GDP growth, we also use the interest rate and consumer expectations as alternative proxies for robustness checks.

The controls of the baseline model include lagged real housing price growth, real personal disposable income growth, the past real GDP growth of the local economy and the world, and country fixed effects. ${ }^{8}$ We estimate robust standard errors based on country and time clustering. The additional controls of an augmented model are growth of the construction production index, of the rental index, of the unemployment rate, of the consumer confidence index, of the exchange rate, of household debt, and of the interest rate. ${ }^{9}$ To minimize the influence of outliers, the variables of all the regressions are winsorized at $1 \%$ and $99 \%$.

\footnotetext{
${ }^{8}$ The controls are based on demand fundamentals in the housing market such as employment and income (Wheaton and Nechayev 2008; Campbell et al. 2009). We include lagged housing price growth to control for return persistence found in the housing market (Case and Shiller 1989). Based on DiPasquale and Wheaton's model (1992), GDP growth should be significantly correlated to housing market demand. We add the world GDP growth to control for a general globalization effect on local housing markets.

${ }^{9}$ Adding the interest rate and rent in the model will control for housing market investment opportunities. Shiller (2006) argues that house prices should be equal to the present value of future rents. Glaeser et al. (2005) find that new construction is a key variable in explaining why US housing prices have gone up. Meanwhile, credit
} 
We estimate the baseline model for each individual country to study the prevalence of China's effects. To examine whether there are similar effects for other major economies, we replicate the individual country analysis using the real GDP growth of the United States, of the United Kingdom, and of the aggregate of France, Germany, and the United Kingdom in place of that of China.

Regarding our second hypothesis, economics posits that when people have more funds, they will consume and invest more (e.g. Krugman and Wells 2015). Specifically, when Chinese individuals have more funds to invest, some of it will flow into the property market, including markets outside China. Hence, we predict that an increase in investible funds of the Chinese will increase their overseas property investments, which, in turn, will increase the housing price growth of these markets. We call this the investible funds hypothesis. To test this hypothesis, we expand Eq. (1) to

$$
\begin{aligned}
h p g_{\mathrm{j}, \mathrm{t}}= & \mathrm{a} 0+\mathrm{a} 1^{*} \text { China's expected growth opportunities } \mathrm{t}_{\mathrm{t}} \\
& +\mathbf{a} \mathbf{2}^{*} \text { growth of China's investible funds } \mathrm{s}_{\mathrm{t}}+\text { Controls }_{\mathrm{j}, \mathrm{t}}+\mathrm{e}_{\mathrm{j}, \mathrm{t}}
\end{aligned}
$$

We consider three alternative fund measures: the savings rate, aggregate wealth, and wealth per adult. We subsequently focus on the savings rate because we only have data on the latter two measures since year 2000. We predict a positive a2. Since Chinese participants in overseas property markets are likely to be in the upper-middle class or higher because of the relatively high minimum investment outlay, the ideal proxy should capture this group's

\footnotetext{
market terms are used to analyse the causes of the subprime mortgage crisis (e.g. Wheaton and Nechayev 2008; Khandani et al. 2009; Glaeser et al. 2010). The exchange rate may be relevant for international investors, since changes of the exchange rate will have a material impact on foreign investment. Thus, it could have predictive power in our analysis (Chen et al. 2010). Finally, the consumer confidence index is based on the exuberance theory proposed by Akerlof and Shiller (2009), to counter for the recent bubble period.
} 
investible funds. We therefore use the growth of the product of an existing investible funds measure and the Gini index. Larger Gini measures imply greater income inequality within a nation, thereby capturing the ability to accumulate savings and wealth of those in or above the upper-middle classes.

Concerning our third hypothesis, risk is a primary consideration of any investment (Markowitz 1952), including property. Miles (2009) reports a $1 \%$ increase in uncertainty lowers changes in housing starts by almost $1 \%$. However, analogous to the overseas opportunity hypothesis, when risk in China is higher, the Chinese invest less in China and turn to overseas investment. A safe investment has been given as a very important reason for Chinese overseas property purchases (Gu and Talyor 2015; Rubina 2016). Consequently, we expect an increase in risk in China will increase overseas property investments by the Chinese, thus accelerating the growth of foreign housing prices. We call this risk hypothesis. We thus augment Eq. (2) as follows:

$$
\begin{array}{rl}
h_{p p g_{\mathrm{j}, \mathrm{t}}} & \mathrm{a} 0+\mathrm{a} 1^{*} \text { China's expected growth opportunities } \\
& +\mathrm{a} 2^{*} \text { growth of China's investible funds } \mathrm{t}+\mathrm{a} 3^{*} \text { China's risk }_{\mathrm{t}} \\
& + \text { Controls }_{\mathrm{j}, \mathrm{t}}+\text { Risk Controls } s_{\mathrm{j}, \mathrm{t}}+\text { Global Risk Contro }\left.\right|_{\mathrm{t}}+\mathrm{e}_{\mathrm{j}, \mathrm{t}}
\end{array}
$$

The prediction is that a3 is positive. We have four Chinese risk measures: political, economic, and financial risk ratings and the proportion of risk or uncertainty stories, estimated as the ratio of the number of risk and uncertainty stories to the number of all stories. Since the ratings are inverse risk measures, their coefficients are expected to be negative. We simultaneously incorporate these different risk measures and use local risk 
counterparts as new controls. We also include global risk controls because foreign housing markets are integral parts of the world.

As our final hypothesis, China's effects predicted by the three hypotheses above are likely to vary across countries. The variation conceivably depends on how familiar the Chinese are with the countries in question (e.g. Coval and Moskowitz 1999; Grinblatt and Keloharju 2001; Huberman 2001; Ivkovíc and Weisbenner 2005; Massa and Simonov 2006) and how attractive these markets are to the Chinese, including aspects such as English being the primary language and quality tertiary education (e.g. Figlio and Lucas 2004). In other words, familiarity and attractiveness are expected to moderate the Chinese effects on the growth of foreign housing prices. We therefore modify Eq. (3) accordingly:

$$
\begin{aligned}
& h p g_{\mathrm{j}, \mathrm{t}}=\mathrm{a} 0+\mathrm{a} 1^{*} \text { China's expected growth opportunities } \mathrm{t}_{\mathrm{t}} \\
& +\mathrm{a} 2 * \text { growth of China's investible funds } \mathrm{t}_{\mathrm{t}}+\mathrm{a}{ }^{*}{ }^{*} \text { China's risk } k_{\mathrm{t}} \\
& + \text { Controls }_{\mathrm{j}, \mathrm{t}}+\text { Risk Controls }_{\mathrm{j}, \mathrm{t}}+\text { Global Risk Control } \mathrm{t} \\
& \text { + a1m* Familiarity } y_{\mathrm{j}, \mathrm{t}, \mathrm{I}} / \text { Attractiveness }_{\mathrm{j}(\mathrm{t}) \mathrm{t}} * \text { China's expected growth opportunities }_{\mathrm{t}}
\end{aligned}
$$

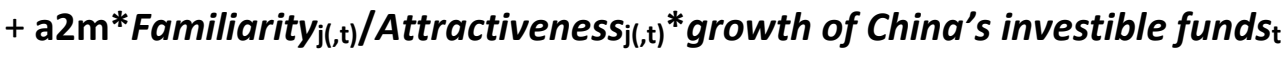

$$
\begin{aligned}
& + \text { a3m }^{*} \text { Familiarity }_{\mathrm{j}(, \mathrm{t})} / \text { Attractiveness }_{\mathrm{j}(\mathrm{t})}{ }^{*} \text { China's risk }+\mathrm{e}_{\mathrm{j}, \mathrm{t}}
\end{aligned}
$$

If a familiarity/attractiveness attribute strengthens (weakens) the Chinese effects, a1m will be negative (positive) and a $2 \mathrm{~m}$ and a $3 \mathrm{~m}$ positive (negative). The main effects of the familiarity/attractiveness attributes are not incorporated for a more parsimonious model because either there is no main standalone effect or the main standalone effect cannot be estimated with country fixed effects. 
The attributes we consider sequentially and cumulatively are the correlation between China's interest rate and the growth of overseas housing prices (reflecting diversification benefits), primary languages, and quality of higher education. Modern portfolio theory (Markowitz 1952) states that whether we add an asset to an existing portfolio depends on the asset's incremental risk effect on the portfolio. If the asset is strongly positively (weakly) correlated with the portfolio, there is little (more) room for risk reduction. Therefore, an investor is more likely to invest in an asset if its correlation with the investor's existing portfolio is lower. The return series of the Chinese portfolio is not readily available. However, as the home bias literature suggests, the Chinese likely mainly hold assets in China. It is thus plausible to use a series that reasonably tracks changes of the returns of Chinese assets over time as a proxy for the return series of the Chinese portfolio. In particular, we use the prime lending rate. ${ }^{10}$ We have two correlation measures: correlation based on all noncontemporaneous observations and correlation for odd (even) quarters based on even (odd) quarter observations.

Since English is a principal international language, we expect the Chinese to be more familiar with countries where English is the primary language (English countries). We also predict that the benefits associated with English make these countries more attractive to the Chinese. Hence, real estate in English countries will be more appealing to the Chinese. The Chinese effects on housing price growth will thus be stronger among these countries. We also have two English measures: a dummy for countries where English is the primary language (Australia, Canada, Ireland, New Zealand, the United Kingdom, and the United States) and a

\footnotetext{
${ }^{10}$ Several Chinese interest rate series (short-, medium-, and long-term major loan rates, a discount rate, and the prime lending rate) are highly correlated, with coefficients above 0.99 .
} 
dummy for countries where English is the de facto official and primary language (Australia, New Zealand, the United Kingdom, and the United States).

A primary reason for overseas property purchases by the Chinese is for their children's education and migration (e.g. Bradsher and Searcey 2015; Juwai 2016). Therefore, we predict that the Chinese effects are more prevalent for countries with better education. Our two measures of higher education quality are the 2016 QS higher education country-level ranking and a dummy for the 2013 top five tertiary student migration destinations of China. These five countries are the United States, Japan, Australia, the United Kingdom, and South Korea.

We also look at bilateral trade, Chinese outward foreign direct investment, Chinese migration numbers, the overseas Chinese population and Chinese outbound tourists, geographical distance, and the long-term growth forecasts of the foreign economies. ${ }^{11}$ However, these have neither explanatory power nor moderating effects. There are three possible explanations. First, these variables are not good proxies of the relevant familiarity/attractiveness. Second, the data quality is poor. Third, there is no relation along these dimensions.

\section{Empirical results}

\subsection{Main relations}

We first graphically show the relations between housing price growth in international markets and growth in the Chinese GDP and wealth. Figure 1A plots China's GDP growth and the housing price growth of North America, Japan, and the aggregate of the 23 countries. The

\footnotetext{
${ }^{11}$ The data sources are the United Nations Comtrade Database (bilateral trade), UNCTAD (foreign direct investment), the World Bank (migration), the OECD (Chinese population and long-term forecasts), www.travelchinaguide.com (tourist numbers), and www.distancecalculator.net (distance)
} 
series are four-quarter moving averages. It is evident that China's GDP growth is negatively correlated with aggregate and North American housing price growth, but not with Japanese housing price growth. In Figure 1B, we replace China's GDP growth in Figure 1A by its wealth growth, where wealth is the product of the total wealth and the Gini index. It is clear that China's wealth growth is fairly strongly positively correlated with the aggregate and North American housing price growth, but not with Japan's.

The remaining graphs show strong corresponding relations for English countries and countries with the top third of QS rankings. The English countries are Australia, Canada, Ireland, New Zealand, the United Kingdom, and the United States. The countries with the top QS rankings are Australia, Canada, France, Germany, the United Kingdom, and the United States. Figures 2A and 2C show China's GDP growth and Figures 2B and 2D display China's wealth growth.

\subsection{Effects of China's GDP growth}

Table 3 reports the regression results of the relation between China's rolling average real quarterly GDP growth over the past four quarters (past GDP growth) and the housing price growth of the other markets around the world. The coefficient of China's past GDP growth is significantly negative. This result is consistent with the overseas opportunity hypothesis, that when China's growth opportunities are poorer, the Chinese buy more overseas properties, whereby increasing the growth of these markets' housing prices. ${ }^{12}$

\footnotetext{
${ }^{12}$ We regress China's real housing price index growth on China's contemporaneous or lagged real GDP growth. The coefficient of the GDP growth is significantly positive. When we replace the above GDP growth by the average of the GDP growth over the past four quarters, the coefficient is still positive but weaker. These results are consistent with the view that lower GDP growth in China reflects a lack of investment opportunities in China's domestic market, including the domestic property market, consistent with the overseas opportunity hypothesis.
} 
The result is robust with respect to the inclusion of various controls, as shown in columns (1) to (3) of Table 3. The coefficients of the controls are generally consistent with expectations. Moreover, the negative relation also exists for an extended sample period, ${ }^{13}$ over which we convert pre-1992 China's annual GDP growth into quarterly GDP growth and use the average of the pre-1992 quarterly variables of all quarters in the corresponding year, although the relation is weaker in the earlier period. In addition, the literature (e.g. Deng et al. 2011; Dokko et al. 2011; Krishnamurthy and Vissing-Jorgensen 2011; Kapetanios et al. 2012; Wu et al. 2012; Xu and Chen 2012) suggests that relations may be different since the recent global financial crisis. However, we find that the significantly negative relation persists when separating the differential effect of the post-2007 period.

We perform several other robustness checks. ${ }^{14}$ First, instead of using the past four quarters, we look at China's GDP growth based on past the one-, two-, and 12-quarter intervals. All alternative intervals of past GDP growth have significantly negative relations with overseas housing price growth. The longer the past GDP growth interval, the larger the estimated coefficients. The magnitude of the coefficient for 12-quarter GDP growth $(-0.115)$ is approximately double the one-quarter coefficient $(-0.056)$. Second, in place of past China's GDP growth, we consider China's consumer expectations based on the past one, two, three, and four quarters. In all cases, the relations with foreign housing price growth are significantly negative. Lastly, we replace China's past GDP growth by China's past prime lending rate. We obtain strongly statistically significant and qualitatively the same results. Interestingly, the

\footnotetext{
In addition, consistent with the investible funds hypothesis, we find that Chinese property market returns are significantly and positively correlated with our measures of wealth or investible funds with Chinese investors.

${ }^{13}$ The start date varies across countries, depending on data availability.

${ }^{14}$ These results are not tabulated but are available from the authors upon request.
} 
magnitude of the estimated coefficient of China's prime lending rate $(-0.086)$ is very close to that of China's GDP growth.

Table 4 summarizes the baseline results of 23 individual countries and the aggregate of these countries. Negative effects of China's past GDP growth on housing price growth are observed in $82.6 \%$ of the countries. Among $52.6 \%$ of these countries, a statistically significant relation, at $10 \%$ or stronger, exists. For the United States, the United Kingdom, and the aggregate, the significance level is $1 \%$ or stronger. The table also shows that past US and UK GDP growth do not have the same pervasive relations with housing price growth in other markets that we see for China's GDP growth. To compare with the effects of a larger European economy, presumably with more significant influence elsewhere, we combine the French, German, and British GDPs. We find that the combined GDP growth also does not have comparable pervasive effects on international housing price growth.

\subsection{Effects of China's changes in saving or wealth growth}

Table 5 tests and supports the investible funds hypothesis. The estimated coefficients of all three measures of the growth of China's investible funds are strongly significantly positive at the $1 \%$ level. ${ }^{15}$ These results are consistent with the notion that, when the Chinese have more investible funds, they generally increase overseas housing purchases, thereby increasing the growth of foreign housing prices. Like the GDP growth results, these investible funds effects are unlikely to be replicated for US wealth growth because the correlation between the wealth growth in China and in the United States is only 0.2. Meanwhile, China's

\footnotetext{
${ }^{15}$ Wealth and the savings rate without Gini interaction also have significant results. However, the saving results are stronger with Gini interaction, whereas wealth and wealth per adult have similar results whether we interact them with the Gini coefficient or not.
} 
past GDP growth remains significantly negative, with a slightly larger magnitude (changing from -0.08 to a range from -0.09 to -0.11 ).

\subsection{Effects of China's risk}

Table 6 shows the relations between the different risk measures and housing price growth based on international panel data. In support of the risk hypothesis, the estimated coefficient of China's economic risk rating is significantly negative. This result suggests that, when China's economic risk is higher (represented by a lower rating index value), the Chinese will invest more in foreign property markets, thereby accelerating foreign housing price growth. ${ }^{16}$ In addition, China's proportion of stories concerning risk or uncertainty has a significantly positive estimated coefficient. When there are more Chinese risk stories, therefore, the Chinese are likely to increase overseas housing investment, which, in turn, increases the corresponding housing price growth. The other Chinese risk measures are insignificant, except for the political risk rating, which is significantly positive when the risk story variables are excluded. ${ }^{17,18}$

As for the local country risk measures, the coefficient of the economic risk rating is positive and strongly significant at the $1 \%$ level, suggesting higher housing price growth when the local economy is more stable. With regard to the world risk measures, the financial rating has a significantly positive coefficient, whereas the proportion of risk stories has a strongly

\footnotetext{
${ }^{16}$ Since China's and the world's financial risk ratings are highly correlated (0.726), we drop China's financial risk rating and rerun the regressions. The results stand.

${ }^{17}$ China's political risk and the world's proportion of stories about risk/uncertainty are positively correlated. Therefore, it is possible for China's political risk rating to be significantly positive (insignificant) when the risk story variables are excluded (included) if the world's risk story variable subsumes China's political risk.

${ }^{18}$ We also separately consider changes in China's original and relative corruption perception indices and changes in China's corruption controls. We find no significant relationship.
} 
significantly negative coefficient. Hence, when the world faces lower financial risk or appears in fewer risk stories, housing prices around the world generally grow faster.

Importantly, China's past GDP growth is still negative and strongly significant at the $1 \%$ level. The estimated coefficient is -0.229 . Hence, on average, a $1 \%$ decrease in China's past GDP precedes overseas housing price increases of approximately $0.23 \%$. This represents an economically significant impact, given the approximate 2015 global residential real estate value of US\$163 trillion, which is double the world GDP and represents roughly $45 \%$ of mainstream global assets (Savills 2016). Furthermore, the change in China's savings rate also remains significantly positive. The estimated coefficient of 0.104 indicates that a $1 \%$ increase in China's savings rate is associated with a $0.1 \%$ increase in international housing prices.

As a robustness check with respect to bubbles in China, we use several time dummies in various regressions to capture the effects of bubbles in China's stock markets between June 2005 and October 2007 and between July 2014 and September 2015, and in China's property markets between 2005 and 2011. We find that our results remain. ${ }^{19}$

\subsection{Modifying effects of correlation with China's interest rate}

Table 7 reveals how Chinese effects vary with the correlation between China's interest rate and local housing price growth. The interaction between the correlation and changes in China's savings rate is significantly negative. Consistent with modern portfolio theory, Chinese investible funds effects are thus generally stronger when the correlation is lower. ${ }^{20}$ However, the interaction between the correlation and China's economic risk rating is also significantly

\footnotetext{
${ }^{19}$ We thank Richard Taffler for the suggestions of controlling for the Chinese stock market and housing bubbles. These results are not tabulated but are available from the authors upon request.

${ }^{20}$ The effect of the growth of China's investible funds becomes the coefficient of investible fund growth itself plus the coefficient of the interaction with the correlation and the investible fund growth.
} 
negative. This finding suggests housing prices grow faster when China experiences better economic stability and the correlation between China's interest rate and local housing price growth is lower. This can be understood as follows. When China is more economically stable, Chinese people will have stronger incentive to invest at home. Hence, during these times, only those foreign housing markets with higher diversification benefits will attract more Chinese purchases in relation to those markets with lower diversification benefits. The remaining correlation interactions are not robustly significant.

\subsection{Differential Chinese effects for English countries}

The second attribute we consider is the English language. As shown in Table 8, consistent with expectations, we find that the dummies for English countries interacted with China's past GDP growth and with the change in China's savings rate are significantly stronger and have the same signs as these Chinese variables before. These results correspondingly show more pronounced Chinese GDP growth and investible funds effects for English than for non-English countries. There is no significant incremental Chinese risk effect on the housing price growth of English over non-English countries.

\subsection{Education matters}

Table 9 reports the moderation of the Chinese effects by the education quality in the overseas market. The interaction between education and China's political risk rating is negative. This finding suggests that, when China is more politically unstable, the overseas housing markets of countries with higher-quality education are more attractive to the Chinese, who then probably purchase more in these markets and housing prices grow faster. Hence, education magnifies China's political risk effects on housing price growth. On the other hand, the interaction between education and China's economic risk rating is significantly positive. 
Hence, education strengthens the Chinese effects on overseas housing price growth when China is more economically stable, thereby enabling the Chinese buyers to generate more funds. The remaining educational interaction terms are insignificant at the standard levels.

Plausibly, English countries and countries with better education also have non-English language and non-educational characteristics attractive to Chinese buyers. One obvious candidate is those attributes associated with the level of economic development. Therefore, we examine whether measures of economic development replicate the English language and education results. In particular, we look at two such measures: a dummy for the G7 and the real GDP per capita. We find that the results do not reproduce the English and education results. Hence, the latter are unlikely to be driven by attributes associated with developed economies.

\section{Conclusions}

Using the data of 23 countries mainly from 1993 to 2015, we document the Chinese effects on the price growth of residential real estate markets around the world. On average, an approximately $0.23 \%$ increase in housing prices follows a $1 \%$ decrease in China's GDP growth or a $2.3 \%$ increase in China's savings rate. These results are consistent with the notion of an increase in Chinese overseas property purchases following the deterioration of China's growth opportunities or an increase in Chinese's investible funds. These Chinese effects are stronger for English countries. Property markets that have a lower correlation with China's interest rate also exhibit more pronounced investible funds effects.

When China's economic risk is higher or China has more risk/uncertainty stories, foreign housing prices also grow faster. This result suggests that higher risk in China drives the Chinese to invest more in overseas housing markets, thereby accelerating corresponding 
price growth. In addition, when China is more economically stable, real estate prices grow faster for countries with two conditions, better education and lower correlation between their housing markets and the China's interest rate. Finally, when China is politically riskier, real estate prices grow faster for China's top tertiary student migration destinations.

This study has a number of limitations that may provide future research directions. For example, there are relatively few exogenous shocks during our sample period that can be used for robustness. Future research could examine how macro-prudential, capital control and market specific measures or policies affect various housing markets differently. 


\section{References}

Aizenman, J., Jinjarak, Y., 2009, Current account patterns and national real estate markets, Journal of Urban Economics, 66, 75-89.

Akerlof, G.A., Shiller, R.J., 2009, Animal Spirits: How Human Psychology Drives the Economy, and Why It Matters for Global Capitalism, Princeton University Press.

Bloomberg, 2017, China's army of global homebuyers is suddenly short on cash, 27 January, retrieved on $15 \quad$ March 2017 from https://www.bloomberg.com/news/articles/2017-01-26/world-s-biggest-real-estate-buy ers-are-suddenly-short-on-cash.

Bradsher, K., Searcey, D., 2015, Chinese cash floods U.S. real estate market, The New York Times, 28 November, retrieved on 11 November 2016 from http://www.nytimes.com/2015/11/29/business/international/chinese-cash-floods-usreal-estate-market.html? $r=0$.

Burnside, C., Eichenbaum, M., Rebelo, S., 2016, Understanding booms and busts in housing markets, Journal of Political Economy, 124(4), 1088-1147.

Calvo, G.A., Leiderman, L., Reinhart, C. M., 1993, Capital inflows and real exchange rate appreciation in Latin America, IMF Staff Papers, 40 (1), 108-151.

Calvo, G.A., Leiderman, L., Reinhart, C.M., 1996, Inflows of capital to developing countries in the 1990s, Journal of Economic Perspectives, 10 (Spring), 123-139.

Campbell, S.D., Davis, M.A., Gallin, J., Martin, R.F., 2009, What moves housing markets: A variance decomposition of the rent-price ratio, Journal of Urban Economics, 66, 90-102.

Case, K.E., Shiller, R.J., 1989, The efficiency of the market for single-family homes, American Economic Review, 79 (1), 125-137.

Chen, Y., Glenn, E., 2017, China's overseas property purchases, investments slump as capital controls bite, Reuters, 16 February 2017, retrieved on 31 August 2017 from http://www.reuters.com/article/us-china-economy-fdi-idUSKBN15VODB.

Chen, Y., Rogoff, K., Rossi, B., 2010, Can exchange rates forecast commodity prices, Quarterly Journal of Economics, 125(3), 1145-1194.

Chuhan, P., Claessens, S., Mamingi, N., 1998, Equity and bond flows to Latin America and Asia: The role of global and country factors, Journal of Development Economics, 55 (April), 439-63.

Cotter, J., Gabriel, S., Roll, R., 2015, Can housing risk be diversified? A cautionary tale from the housing boom and bust, Review of Financial Studies, 28(3), 913-936.

Coval, J., Moskowitz, T., 1999, Home bias at home: Local equity preference in domestic portfolios, Journal of Finance, 54, 1697-1704. 
Crédit Suisse, 2015, Global Wealth Databook 2015, op. cit..

Deng, Y., Morck, R., Wu, J., Yeung, B., 2011, Monetary and fiscal stimuli, ownership structure, and China's housing market, NBER Working Paper 16871.

DiPasquale, D., Wheaton, W.C., 1992, The markets for real estate assets and space: A conceptual framework, Journal of the American Real Estate and Urban Economics Association, 20(1), 181-197.

Dmitrieva, K., 2016, Chinese buyers hungry for Canadian homes with inquiries up 134\%, Bloomberg, 14 April, retrieved on 16 September 2016 from http://www.bloomberg.com/news/articles/2016-04-13/chinese-buyers-hungry-forcanadian-homes-with-inquiries-up-134.

Dokko, J., Doyle, B.M., Kiley, M.T., Kim, J., Sherlund, S., Sim, J., Heuvel, S.V.D., 2011, Monetary policy and the global housing bubble, Economic Policy, 26(66), 233-283.

Farrell, R., 1997, Japanese foreign direct investment in real estate 1985-1994, Pacific Economic Papers, No. 272, Australia - Japan Research Centre.

Favilukis, J., Kohn, D., Ludvigson, S.C., Nieuwerburgh, S.V., 2013, International capital flows and house prices: Theory and evidence, in Housing and the Financial Crisis, edited by Glaeser, E.L. and Sinai, T., University of Chicago Press, pp. 235-299.

Fernandez-Arias, E., 1996, The new wave of private capital inflows: Push or pull? Journal of Development Economics, 48 (March), 389-418.

Figlio, D.N., Lucas, M.E., 2004, What's in a grade? School report cards and the housing market, American Economic Review, 94(3), 591-604.

Fratzscher, M., 2012, Capital flows, push versus pull factors and the global financial crisis, Journal of International Economics, 88(2), 341-356.

Glaeser, E.L., Gyourko, J., Saks, R.E., 2005, Urban growth and housing supply, Journal of Economic Geography, 6(1), 71-89.

Glaeser, E., Gottlieb, J., Gyourko, J., 2010, Can cheap credit explain the housing boom? NBER Working Paper No. 16230.

Grant, P., 2016, Chinese investors pour money Into U.S. property, The Wall Street Journal, 25 May, retrieved on 16 September 2016 from http://www.wsj.com/articles/chineseinvestors-pour-money-into-u-s-property-1464110682.

Grinblatt, M., Keloharju, M., 2001, How distance, language and culture influence stockholdings and trades, Journal of Finance, 56, 1053-1073. 
Gu, W., Talyor R., 2015, Market turmoil seen spurring China property purchases overseas, The Wall Street Journal, 27 August, retrieved on 11 November 2016 from http://www.wsj.com/articles/australia-worried-about-rise-in-chinese-property-buying1440654099.

Hott, C., Monnin, P., 2008, Fundamental real estate prices: An empirical estimation with international data, Journal of Real Estate Finance and Economics, 36, 427-450.

Huberman, G., 2001, Familiarity breeds investment, Review of Financial Studies, 14, 659680.

Ivkovíc, Z., Weisbenner, S., 2005, Local does as local is: Information content of the geography of individual investors' common stock investment, Journal of Finance, 60(1), 267-306.

Juwai, 2016, 6 reasons why education underpins Chinese overseas property investment, 5 July, retrieved on 11 November 2016 from https://list.juwai.com/news/2016/07/6reasons-why-education-underpins-chinese-overseas-property-investment.

Kapetanios, G., Mumtaz, H., Stevens, I., Theodoridis, K., 2012, Assessing the economywide effects of quantitative easing, Economic Journal, 122, 316-347.

Khandani, A., Lo, A.W., Merton, R.C., 2009, Systemic risk and the refinancing ratchet effect, NBER Working Paper No. 15362.

Krishnamurthy, A., Vissing-Jorgensen, A., 2011, The effects of quantitative easing on interest rates: channels and implications for policy, NBER Working Paper No. 17555.

Krugman, P., Wells, R., 2009, Macroeconomics, Worth Publishers.

La Porta, R., Lopez-De-Silanes, F., Shleifer, A., Vishny, R.W., 1997, Legal determinants of external finance, Journal of Finance, 52(3), 1131-1150.

Lai, R.N., van Order, R.A., 2010, Momentum and house price growth in the United States: Anatomy of a bubble, Real Estate Economics, 38(4), 753-773.

Lemmon, M., Portniaguina, E., 2006, Consumer confidence and asset prices: Some empirical evidence, Review of Financial Studies, 19(4), 1499-1529.

Mack, A., Martínez-García, E., 2011, A cross-country quarterly database of real house prices: A methodological note, Globalization and Monetary Policy Institute Working Paper No. 99.

Markowitz, H., 1952, Portfolio selection, Journal of Finance, 7(1), 77-91.

Markowitz, H., 1999, The early history of portfolio theory: 1600-1960, Financial Analysts Journal, 55(4), 5-16. 
Massa, M., Simonov, A., 2006, Hedging, familiarity, and portfolio choice, Review of Financial Studies, 19, 633-685.

McEachern, W.A., 2011, Economics: A contemporary introduction. Cengage Learning.

Meyer, R., Wieand, K., 1996, Risk and return to housing, tenure choice and the value of housing in an asset pricing context, Real Estate Economics, 24(1), 113-131.

Mian, A., Sufi, A., Trebbi, F., 2015, Foreclosures, house prices, and the real economy, Journal of Finance, 70(6), 2587-2634.

Miles, W., 2009, Irreversibility, uncertainty and housing investment, Journal of Real Estate Finance and Economics, 38(2), 173-182.

Nelson, P., 1970, Information and consumer behaviour, Journal of Political Economy, 78(2), 311-329.

Newell, G., Worzala, E., 1995, The role of international property in investment portfolios. Journal of Property Finance, 6(1), 55-63.

NZ Herald, 2016, Chinese buyers coming back to Auckland property market, 6 March, retrieved on 16 September 2016 from http://www.nzherald.co.nz /business/news/article.cfm?c_id=3\&objectid=11600974.

Rapoza, K., 2016, The flipside of China's love for American real estate, Forbes, 16 May, retrieved on 16 September 2016 from http://www.forbes.com/sites /kenrapoza/2016/05/16/the-flipside-of-chinas-love-for-american-realestate/\#4bec60c240e8.

Reserve Bank of Australia, 2016, Financial Stability Review April 2016.

Reuters, 2016, Why Chinese investment in overseas real estate has more than doubled, 18 August, retrieved on 16 September 2016 from http://fortune.com/ 2016/08/18/chinaoverseas-property-investment/.

Rodríguez, C., Bustillo, R., 2010, Modelling foreign real estate investment: The Spanish case, Journal of Real Estate Finance and Economics, 41, 354-367.

Rubina Real Estate, 2016, Chinese International Property Investment Trends in 2016, retrieved on 11 November 2016 from http://www.rubinarealestate.com/en/china/ china2016-international-property-investment-overview/.

Saiz, A., 2003, Room in the kitchen for the melting pot: Immigration and rental prices, Review of Economics and Statistics, 85(3), 502-521.

Savills, 2016, World real estate accounts for $60 \%$ of all mainstream assets, 25 January, retrieved on 18 September 2016 from http://www.savills.co.uk/ _news/article/72418/198559-0/1/2016/world-real-estate-accounts-for-60--of-allmainstream-assets. 
Sheng, E., 2017, Chinese Overseas Real Estate Buying Spree Slows, Delayed By Tightened Capital Controls, Forbes, 31 July 2017 retrieved on 31 August 2017 from https://www.forbes.com/sites/ellensheng/2017/07/31/chinese-overseas-real-estatebuying-spree-slows-delayed-by-tightened-capital-controls/\#32c7c4de14f7.

Shiller, R.J., 2006, Long-term perspective on the current boom in home prices, The Economist's Voice 3.

Solt, F., 2016, The standardized world income inequality database, Social Science quarterly, 97(5), 1267-1281.

A roaring trade, 18 June 2016, The Economist, retrieved on 1 December 2016 from http://www.economist.com/news/united-states/21700660-chinese-tiger-mums-startcollege-town-housing-boom-roaring-trade.

Maple grief, 17 - 23 June 2017, The Economist.

Wheaton, W.C., Nechayev, G., 2008, The 1998-2005 housing "bubble" and the current "correction": What's different this time? Journal of Real Estate Research, 30, 1-26.

Wu, J., Gyourko, J., Deng, Y., 2012, Evaluating conditions in major Chinese housing markets, Regional Science and Urban Economics, 42, 531-543.

Xu, X.E., Chen, T., 2012, The effect of monetary policy on real estate price growth in China, Pacific-Basin Finance Journal, 20, 62-77.

Yang, Y., 2016, Beijing clampdown slows China spending spree on US property, Financial Times, 16 May, retrieved on 16 September 2016 from https://www.ft.com/content/e1c2aa44-1b37-11e6-8fa5-44094f6d9c46.

Yao, R., Zhang, H.H., 2005, Optimal consumption and portfolio choices with risky housing and borrowing constraints, Review of Financial Studies, 18(1), 197-239. 


\begin{tabular}{|c|c|}
\hline Variable & Definition \\
\hline$C$ & Takes a value of 1 for observations since 2008 Q1, 0 otherwise \\
\hline $\operatorname{ccg}$ & Growth in the seasonally adjusted consumer confidence indicator \\
\hline cn_EconomicRiskRating & Economic risk rating of China's economy; a larger value represents lower risk \\
\hline cn_FinancialRiskRating & Financial risk rating of China's economy; a larger value represents lower risk \\
\hline cn_pastGDPgrowth after 1992 & Average of quarterly growth in China's real GDP over the past 4 quarters \\
\hline cn_pastGDPgrowth before or in 1992 & Quarterly growth from annual growth in China's real GDP \\
\hline cn_PoliticalRiskRating & Political risk rating of China's economy; a larger value represents lower risk \\
\hline cn_RiskStoryNum/TotalStoryNum & Ratio of the number of risk stories to the number of all stories for China \\
\hline cnSaving & $\begin{array}{l}\text { China's gross domestic savings, calculated as GDP less final consumption expenditure (total consumption), \% of } \\
\text { GDP. }\end{array}$ \\
\hline cnWealth & China's total wealth, in US dollars \\
\hline cnWealth per adult & China's wealth per adult, in US dollars \\
\hline constrg & Growth in the seasonally adjusted index of production in construction \\
\hline $\operatorname{corr}($ measure 1$)$ & $\begin{array}{l}\text { Correlation between China's interest rate (prime lending rate, cnint) and the growth of the housing price of the } \\
\text { local property market (hpg) }\end{array}$ \\
\hline corr (measure 2) & $\begin{array}{l}\text { Correlation between China's interest rate (prime lending rate, cnint) and the growth of the housing price of the } \\
\text { local property market (hpg) }\end{array}$ \\
\hline d_cnSaving*Gini & Change in China's savings rate \\
\hline debtg & $\begin{array}{l}\text { Growth in annual household debt. Household debt is defined as all liabilities that require payment or payments } \\
\text { of interest or principal by a household to a creditor at a date or dates in the future. Consequently, all debt } \\
\text { instruments are liabilities, but some liabilities - such as shares, equity, and financial derivatives - are not } \\
\text { considered debt. According to the } 1993 \text { System of National Accounts, debt is thus obtained as the sum of the } \\
\text { following liability categories, whenever available/applicable in the financial balance sheet of households and } \\
\text { non-profit institutions serving the household sector: currency and deposits; securities other than shares, except } \\
\text { financial derivatives; loans; insurance technical reserves; and other accounts payable. For households, liabilities } \\
\text { predominantly consist of loans, particularly mortgage loans for the purchase of houses. This indicator is } \\
\text { measured as a percentage of net disposable income. }\end{array}$ \\
\hline
\end{tabular}




\begin{tabular}{|c|c|}
\hline Variable & Definition \\
\hline DisposableIncomeGrowth & Growth in real personal disposable income \\
\hline DisposablelncomeGrowth(t-1) & DisposablelncomeGrowth of the previous quarter \\
\hline Edu (measure 1) & Country-level ranking of the 2016 QS world university ranking \\
\hline Edu (measure 2) & Takes a value of 1 for the top five tertiary student destinations of China in 2013, 0 otherwise \\
\hline Eng (measure 1) & Takes a value of 1 where English is the primary language, 0 otherwise \\
\hline Eng (measure 2) & Takes a value of 1 where English is the de facto official and primary language, 0 otherwise \\
\hline exg & Growth in the exchange rate \\
\hline g_cnWealth*Gini & Growth in China's wealth \\
\hline g_cnWealth per adult ${ }^{*}$ Gini & Growth in China's wealth per adult \\
\hline Gini & China's Gini coefficient \\
\hline HousingPriceGrowth (hpg) & Growth in the real housing price index \\
\hline HousingPriceGrowth(t-1) & hpg of the previous quarter \\
\hline interestg & $\begin{array}{l}\text { Growth in the short-term interest rate. Short-term interest rates are the rates at which short-term borrowings } \\
\text { are implemented between financial institutions or the rate at which short-term government paper is issued or } \\
\text { traded in the market. Short-term interest rates are generally averages of daily rates, measured as a percentage. } \\
\text { Short-term interest rates are based on three-month money market rates where available. Typical standardized } \\
\text { terms are money market rate and Treasury bill rate. }\end{array}$ \\
\hline loc_EconomicRiskRating & Economic risk rating of the local economy; a larger value represents lower risk \\
\hline loc_FinancialRiskRating & Financial risk rating of the local economy; a larger value represents lower risk \\
\hline loc_pastGDPgrowth & Average of the quarterly growth in the real GDP of the local economy over the past 4 quarters \\
\hline loc_PoliticalRiskRating & Political risk rating of the local economy; a larger value represents lower risk \\
\hline loc_RiskStoryNum/TotalStoryNum & The ratio of the number of risk stories to the number of all stories for the country \\
\hline permitg & Growth in seasonally adjusted permits index issued for dwellings/residential buildings. \\
\hline rentg & Growth in the seasonally adjusted rental price index \\
\hline urateg & Growth in the seasonally adjusted unemployment rate \\
\hline wd_EconomicRiskRating & Average economic risk rating of all countries; a larger value represents lower risk \\
\hline wd_FinancialRiskRating & Average financial risk rating of all countries; a larger value represents lower risk \\
\hline wd_pastGDPgrowth & Average of the quarterly growth in the real world GDP over the past 4 quarters \\
\hline
\end{tabular}

Page 29 of 47 


\section{Variable}

wd_PoliticalRiskRating

wd_RiskStoryNum/TotalStoryNum

\section{Definition}

Average political risk rating of all countries; a larger value represents lower risk

Ratio of the number of risk stories to the number of all stories for the world 


\begin{tabular}{|c|c|c|}
\hline Variable & Frequency & Calculation \\
\hline C & Monthly & \\
\hline $\operatorname{ccg}$ & Monthly & $\begin{array}{l}\text { First calculate the monthly average in a quarter; then calculate the growth of the monthly } \\
\text { average as the quarterly growth by taking the difference in the natural log of the values of } \\
\text { two consecutive quarters }\end{array}$ \\
\hline cn_EconomicRiskRating & Monthly & Average of the monthly ratings in a quarter \\
\hline cn_FinancialRiskRating & Monthly & Average of the monthly ratings in a quarter \\
\hline cn_pastGDPgrowth after 1992 & Quarterly & \\
\hline cn_pastGDPgrowth before or in 1992 & Annual & Quarterly growth $=(1+\text { annual growth })^{0.25}-1$ \\
\hline cn_PoliticalRiskRating & Monthly & Average of the monthly ratings in a quarter \\
\hline cn_RiskStoryNum/TotalStoryNum & Daily & Average of the daily ratio in a quarter \\
\hline cnSaving & Annual & \\
\hline cnWealth & Annual & \\
\hline cnWealth per adult & Annual & \\
\hline constrg & Quarterly & Difference in the natural log of the values of two consecutive quarters \\
\hline corr (measure 1) & Quarterly & $\begin{array}{l}\text { For quarter } t \text {, the correlation calculation is based on all data, but excluding quarter t's data } \\
\text { point }\end{array}$ \\
\hline corr (measure 2) & Quarterly & For odd [even] quarters, the correlation calculation is based on all even [odd] quarters \\
\hline d_cnSaving*Gini & Annual & The first difference of the interaction of cnSaving and Gini, divided by 10,000 \\
\hline debtg & Annual & Difference in the natural log of the values of two consecutive years \\
\hline DisposablelncomeGrowth & Quarterly & Difference in the natural log of the values of two consecutive quarters \\
\hline DisposablelncomeGrowth(t-1) & Quarterly & \\
\hline Edu (measure 1) & 2016 & \\
\hline Edu (measure 2) & One data point & \\
\hline Eng (measure 1) & One data point & \\
\hline Eng (measure 2) & One data point & \\
\hline exg & Monthly & $\begin{array}{l}\text { First calculate the monthly average in a quarter; then calculate the growth of the monthly } \\
\text { average as the quarterly growth by taking the difference in the natural log of the values of } \\
\text { two consecutive quarters }\end{array}$ \\
\hline
\end{tabular}

Page 31 of 47 


\begin{tabular}{|c|c|c|}
\hline Variable & Frequency & Calculation \\
\hline g_cnWealth*Gini & Annual & $\begin{array}{l}\text { Difference in the natural log of the values of the interaction between cnWealth and Gini of } \\
\text { two consecutive years }\end{array}$ \\
\hline g_cnWealth per adult*Gini & Annual & $\begin{array}{l}\text { Difference in the natural log of the values of the interaction between cnWealth per adult } \\
\text { and Gini of two consecutive years }\end{array}$ \\
\hline Gini & Annual & \\
\hline HousingPriceGrowth (hpg) & Quarterly & Difference in the natural log of the values of two consecutive quarters \\
\hline HousingPriceGrowth(t-1) & Quarterly & \\
\hline interestg & Monthly & $\begin{array}{l}\text { First calculate the monthly average in a quarter; then calculate the growth of the monthly } \\
\text { average as the quarterly growth by taking the difference in the natural log of the values of } \\
\text { two consecutive quarters }\end{array}$ \\
\hline loc_EconomicRiskRating & Monthly & Average of the monthly ratings in a quarter \\
\hline loc_FinancialRiskRating & Monthly & Average of the monthly ratings in a quarter \\
\hline loc_pastGDPgrowth & Quarterly & $\begin{array}{l}\text { Quarterly growth is the difference in the natural log of the values of two consecutive } \\
\text { quarters }\end{array}$ \\
\hline loc_PoliticalRiskRating & Monthly & Average of the monthly ratings in a quarter \\
\hline loc_RiskStoryNum/TotalStoryNum & Daily & Average of the daily ratio in a quarter \\
\hline permitg & Quarterly & Difference in the natural log of the values of two consecutive quarters \\
\hline rentg & Quarterly & Difference in the natural log of the values of two consecutive quarters \\
\hline urateg & Monthly & $\begin{array}{l}\text { First calculate the monthly average in a quarter; then calculate the growth of the monthly } \\
\text { average as the quarterly growth by taking the difference in the natural log of the values of } \\
\text { two consecutive quarters }\end{array}$ \\
\hline wd_EconomicRiskRating & Monthly & $\begin{array}{l}\text { First calculate the average rating of all countries in a month; then calculate the average of } \\
\text { the monthly ratings in a quarter }\end{array}$ \\
\hline wd_FinancialRiskRating & Monthly & $\begin{array}{l}\text { First calculate the average rating of all countries in a month; then calculate the average of } \\
\text { the monthly ratings in a quarter }\end{array}$ \\
\hline wd pastGDPgrowth & Quarterly & $\begin{array}{l}\text { Quarterly growth is the difference in the natural log of the values of two consecutive } \\
\text { quarters }\end{array}$ \\
\hline wd_PoliticalRiskRating & Monthly & $\begin{array}{l}\text { First calculate the average rating of all countries in a month; then calculate the average of } \\
\text { the monthly ratings in a quarter }\end{array}$ \\
\hline wd RiskStoryNum/TotalStoryNum & Daily & Average of the daily ratio in a quarter \\
\hline
\end{tabular}

Page 32 of 47 


\begin{tabular}{|l|l|}
\hline Variable & Exceptions \\
\hline$c c g$ & Norway: quarterly \\
\hline constrg & Croatia's Source: Datastream \\
\hline debtg & Croatia, Israel, Luxembourg, New Zealand, and South Africa do not have data \\
\hline Edu (measure 1) & Croatia and Luxembourg do not have data \\
\hline interestg & $\begin{array}{l}\text { Japan, interbank rate (source Datastream); Croatia, credit rate before or in 2004 and T-bill rate after 2004 } \\
\text { (source Datastream) }\end{array}$ \\
\hline permitg & Japan and the US, monthly (source Datastream); Croatia and Italy, quarterly (source Datastream) \\
\hline rentg & Croatia: monthly (source Datastream) \\
\hline urateg & Quarterly: France, Israel, Italy, Luxembourg, the Netherlands, New Zealand, Norway, South Africa, Sweden \\
\hline
\end{tabular}


Table 1. Summary Statistics

The definitions of the variables are given in the Appendix.

\begin{tabular}{|c|c|c|c|c|c|}
\hline Variable & Mean & $\begin{array}{l}\text { Standard } \\
\text { Deviation }\end{array}$ & $25 \%$ & $50 \%$ & $75 \%$ \\
\hline HousingPriceGrowth & $0.54 \%$ & $1.86 \%$ & $-0.56 \%$ & $0.50 \%$ & $1.64 \%$ \\
\hline DisposablelncomeGrowth & $0.35 \%$ & $0.85 \%$ & $-0.09 \%$ & $0.37 \%$ & $0.84 \%$ \\
\hline d_cnSaving*Gini & $0.54 \%$ & $0.83 \%$ & $-0.02 \%$ & $0.40 \%$ & $1.03 \%$ \\
\hline g_cnWealth*Gini & $13.06 \%$ & $12.77 \%$ & $8.32 \%$ & $11.40 \%$ & $23.12 \%$ \\
\hline g_cnWealth per adult*Gini & $11.57 \%$ & $12.76 \%$ & $6.84 \%$ & $9.85 \%$ & $21.42 \%$ \\
\hline cn_pastGDPgrowth & $10.14 \%$ & $2.03 \%$ & $8.38 \%$ & $9.95 \%$ & $11.28 \%$ \\
\hline loc_pastGDPgrowth & $0.58 \%$ & $0.70 \%$ & $0.26 \%$ & $0.64 \%$ & $0.97 \%$ \\
\hline wd_pastGDPgrowth & $0.71 \%$ & $0.35 \%$ & $0.60 \%$ & $0.75 \%$ & $0.95 \%$ \\
\hline loc_PoliticalRiskRating & 82 & 7 & 79 & 84 & 88 \\
\hline loc_FinancialRiskRating & 40 & 5 & 37 & 40 & 44 \\
\hline loc_EconomicRiskRating & 40 & 4 & 38 & 41 & 43 \\
\hline cn_PoliticalRiskRating & 66 & 4 & 62 & 67 & 69 \\
\hline cn_FinancialRiskRating & 45 & 3 & 45 & 46 & 48 \\
\hline cn_EconomicRiskRating & 39 & 2 & 39 & 40 & 41 \\
\hline wd_PoliticalRiskRating & 66 & 2 & 65 & 67 & 68 \\
\hline wd_FinancialRiskRating & 37 & 2 & 35 & 37 & 38 \\
\hline wd_EconomicRiskRating & 35 & 1 & 34 & 35 & 36 \\
\hline loc_RiskStoryNum/TotalStoryNum & $12.15 \%$ & $5.53 \%$ & $7.78 \%$ & $11.50 \%$ & $15.31 \%$ \\
\hline cn_RiskStoryNum/TotalStoryNum & $11.84 \%$ & $4.67 \%$ & $9.11 \%$ & $10.62 \%$ & $14.91 \%$ \\
\hline wd_RiskStoryNum/TotalStoryNum & $14.59 \%$ & $4.44 \%$ & $10.84 \%$ & $15.11 \%$ & $17.16 \%$ \\
\hline corr (measure 1) & -0.18 & 0.25 & -0.38 & -0.24 & 0.02 \\
\hline
\end{tabular}


Table 2. Correlations

The definitions of the variables are given in the Appendix. Here, $h p g$ is HousingPriceGrowth. The bold figures are significant at 5\% or stronger.

\begin{tabular}{|c|c|c|c|c|c|c|c|c|c|c|c|c|c|c|c|c|c|c|c|c|c|c|}
\hline & $\begin{array}{l}h p g \\
(\mathrm{t}-1) \\
\end{array}$ & (1) & (2) & (3) & (4) & (5) & (6) & (7) & (8) & (9) & (10) & (11) & (12) & (13) & (14) & (15) & (16) & (17) & (18) & (19) & (20) & (21) \\
\hline DisposableIncomeGrowth (1) & 0.156 & & & & & & & & & & & & & & & & & & & & & \\
\hline d_cnSaving*Gini (2) & 0.107 & -0.030 & & & & & & & & & & & & & & & & & & & & \\
\hline g_cnWealth*Gini (3) & 0.241 & 0.088 & 0.336 & & & & & & & & & & & & & & & & & & & \\
\hline g_cnWealth per adult ${ }^{*}$ Gini (4) & 0.241 & 0.087 & 0.339 & 1.000 & & & & & & & & & & & & & & & & & & \\
\hline cn_pastGDPgrowth (5) & -0.115 & -0.017 & 0.006 & -0.175 & -0.187 & & & & & & & & & & & & & & & & & \\
\hline loc_pastGDPgrowth (6) & 0.155 & 0.071 & -0.275 & -0.172 & -0.172 & 0.268 & & & & & & & & & & & & & & & & \\
\hline wd_pastGDPgrowth(7) & 0.294 & 0.224 & -0.137 & -0.028 & -0.029 & 0.197 & 0.579 & & & & & & & & & & & & & & & \\
\hline loc_PoliticalRiskRating (8) & 0.207 & 0.079 & 0.089 & 0.067 & 0.066 & -0.074 & 0.040 & 0.010 & & & & & & & & & & & & & & \\
\hline loc_FinancialRiskRating (9) & 0.004 & 0.054 & -0.012 & 0.017 & 0.016 & 0.299 & 0.032 & 0.064 & 0.103 & & & & & & & & & & & & & \\
\hline loc_EconomicRiskRating (10) & 0.291 & 0.166 & 0.084 & 0.016 & 0.014 & 0.102 & 0.323 & 0.353 & 0.520 & 0.367 & & & & & & & & & & & & \\
\hline cn_PoliticalRiskRating (11) & 0.091 & 0.021 & 0.191 & 0.128 & 0.117 & 0.560 & 0.047 & 0.062 & 0.051 & 0.286 & 0.131 & & & & & & & & & & & \\
\hline cn_FinancialRiskRating (12) & -0.013 & -0.053 & 0.085 & -0.180 & -0.184 & -0.250 & -0.079 & -0.215 & 0.012 & -0.467 & -0.080 & -0.359 & & & & & & & & & & \\
\hline cn_EconomicRiskRating (13) & -0.017 & -0.022 & -0.186 & -0.101 & -0.110 & -0.279 & 0.045 & -0.109 & 0.039 & -0.334 & 0.007 & -0.074 & 0.633 & & & & & & & & & \\
\hline wd_PoliticalRiskRating (14) & 0.235 & 0.101 & -0.026 & 0.199 & 0.189 & -0.174 & 0.214 & 0.142 & 0.214 & -0.154 & 0.210 & 0.244 & 0.132 & 0.328 & & & & & & & & \\
\hline wd_FinancialRiskRating (15) & -0.090 & -0.088 & -0.140 & -0.353 & -0.354 & 0.014 & 0.032 & -0.217 & -0.058 & -0.232 & -0.188 & -0.196 & 0.726 & 0.524 & -0.036 & & & & & & & \\
\hline wd_EconomicRiskRating (16) & 0.106 & 0.029 & 0.001 & -0.149 & -0.154 & 0.240 & 0.572 & 0.247 & 0.076 & -0.185 & 0.303 & 0.142 & 0.435 & 0.491 & 0.392 & 0.512 & & & & & & \\
\hline loc_RiskStoryN/TotalStoryN (17) & -0.100 & -0.062 & -0.058 & -0.168 & -0.166 & -0.193 & -0.010 & -0.144 & 0.048 & -0.255 & -0.098 & -0.415 & 0.567 & 0.335 & -0.035 & 0.502 & 0.262 & & & & & \\
\hline cn_RiskStoryN/TotalStoryN (18) & 0.196 & 0.061 & 0.360 & -0.046 & -0.041 & -0.367 & 0.123 & 0.034 & 0.148 & -0.248 & 0.158 & -0.214 & 0.372 & 0.088 & 0.320 & 0.111 & 0.336 & 0.321 & & & & \\
\hline wd_RiskStoryN/TotalStoryN (19) & -0.094 & -0.062 & 0.050 & -0.339 & -0.328 & -0.443 & -0.069 & -0.189 & -0.002 & -0.359 & -0.106 & -0.647 & 0.634 & 0.281 & -0.119 & 0.557 & 0.254 & 0.617 & 0.581 & & & \\
\hline corr (measure 1) (20) & 0.020 & 0.013 & 0.001 & 0.001 & 0.001 & -0.039 & 0.005 & -0.011 & -0.033 & -0.024 & 0.006 & -0.022 & 0.059 & 0.057 & 0.033 & 0.037 & 0.035 & -0.081 & 0.035 & 0.038 & & \\
\hline Eng (measure 1) (21) & 0.078 & 0.085 & 0.010 & 0.002 & 0.002 & 0.022 & -0.005 & 0.116 & 0.203 & -0.289 & -0.208 & 0.012 & -0.037 & -0.041 & -0.030 & -0.036 & -0.028 & 0.059 & -0.015 & -0.026 & 0.015 & \\
\hline$E d u$ (measure 2) (22) & -0.099 & 0.041 & 0.003 & 0.002 & 0.002 & 0.043 & -0.005 & 0.080 & -0.049 & 0.008 & -0.152 & 0.029 & -0.074 & -0.066 & -0.043 & -0.057 & -0.048 & 0.079 & -0.042 & -0.053 & -0.107 & 0.407 \\
\hline
\end{tabular}

Page 35 of 47 
Figure 1A. China's GDP growth and overseas housing price growth

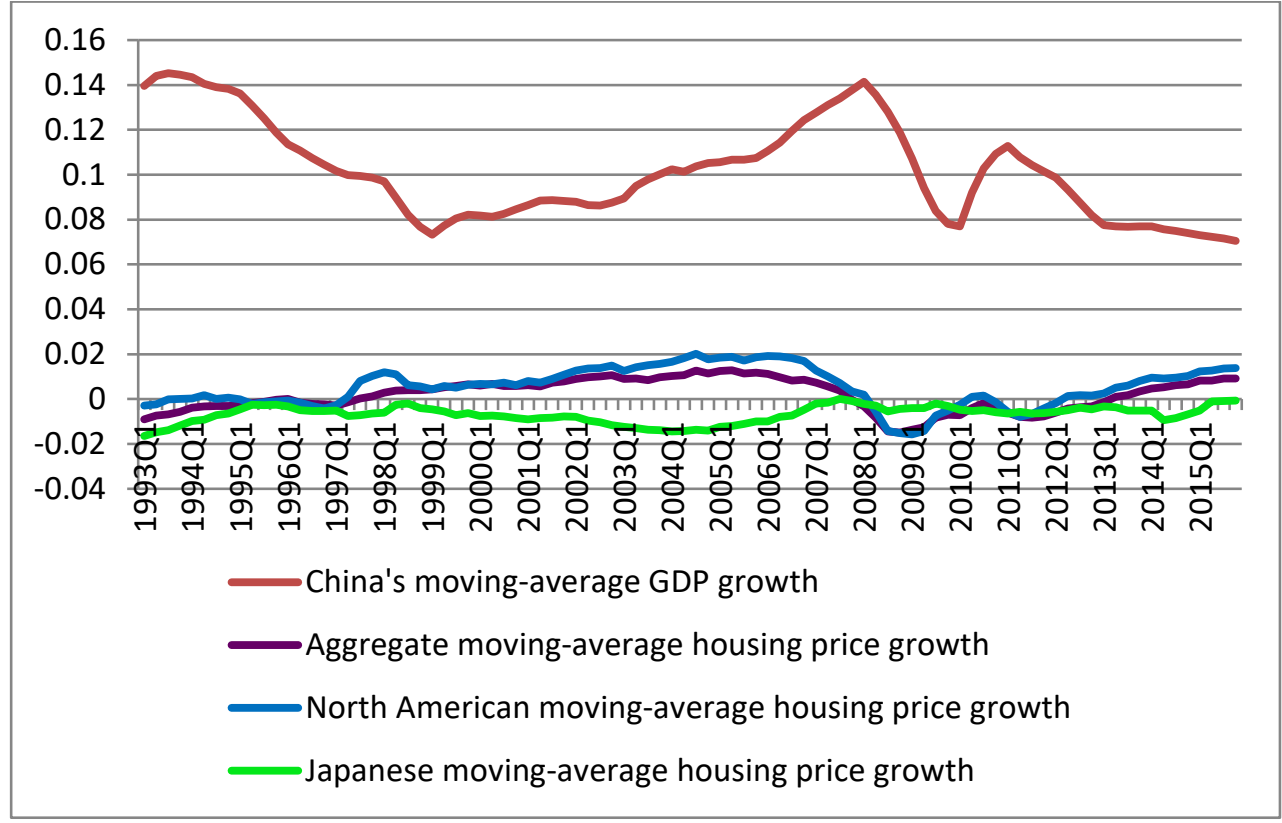

Figure 1B. China's wealth growth and overseas housing price growth

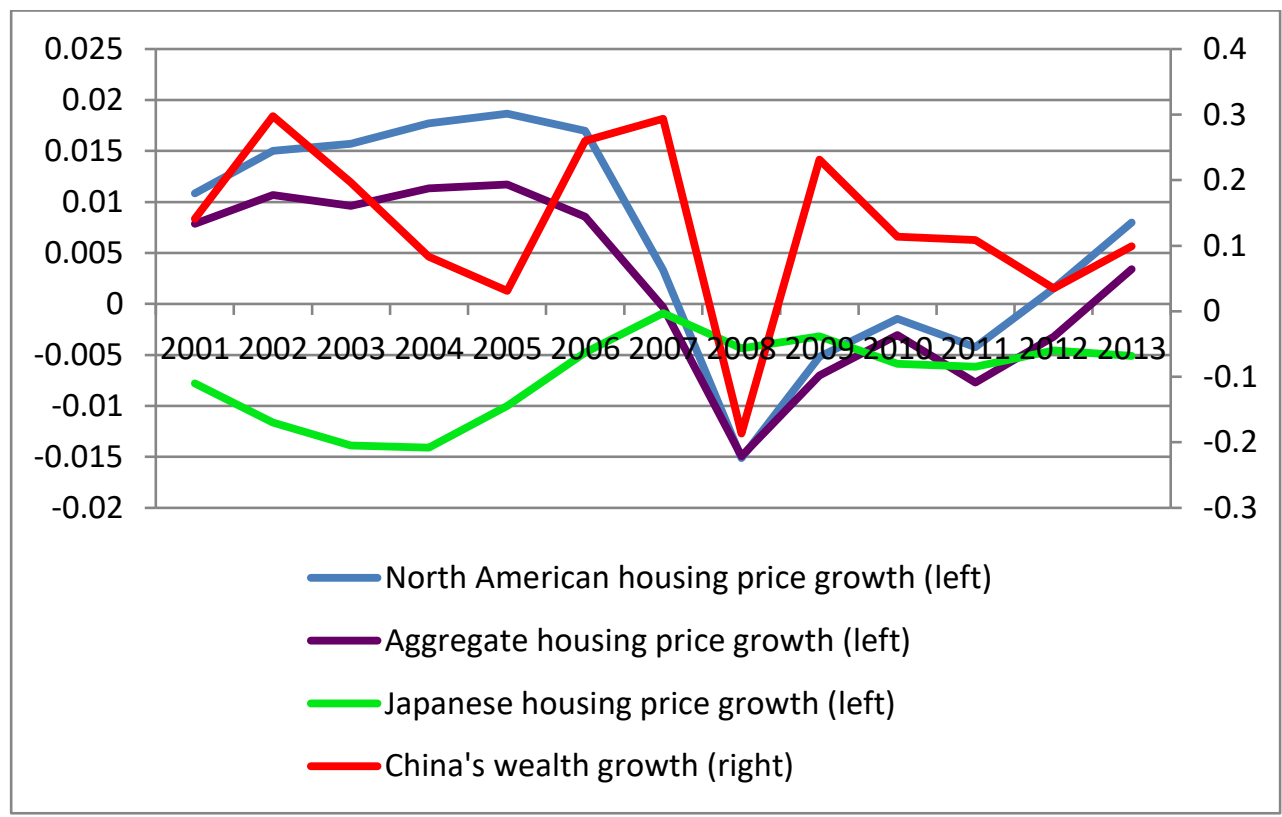

In Figure 1A, China's GDP growth is the average of that of the past four quarters; the housing price growth is the average of that of the contemporaneous and the past three quarters. North America consists of Canada and the United States, weighted by the GDP purchasing power parity per capita. In Figure 1B, China's wealth is the product of total wealth and the Gini coefficient; housing price growth is the average quarterly growth of the four quarters in a year. 
Figure 2A. China's GDP growth and English countries' housing price growth

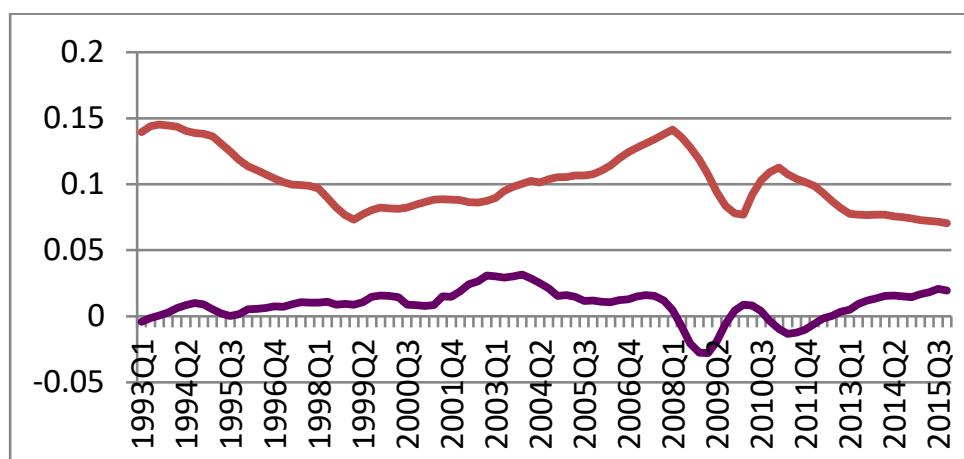

English countries' moving-average housing price growth

China's moving-average GDP growth

Figure 2C. China's GDP growth and high-QS countries' housing price growth

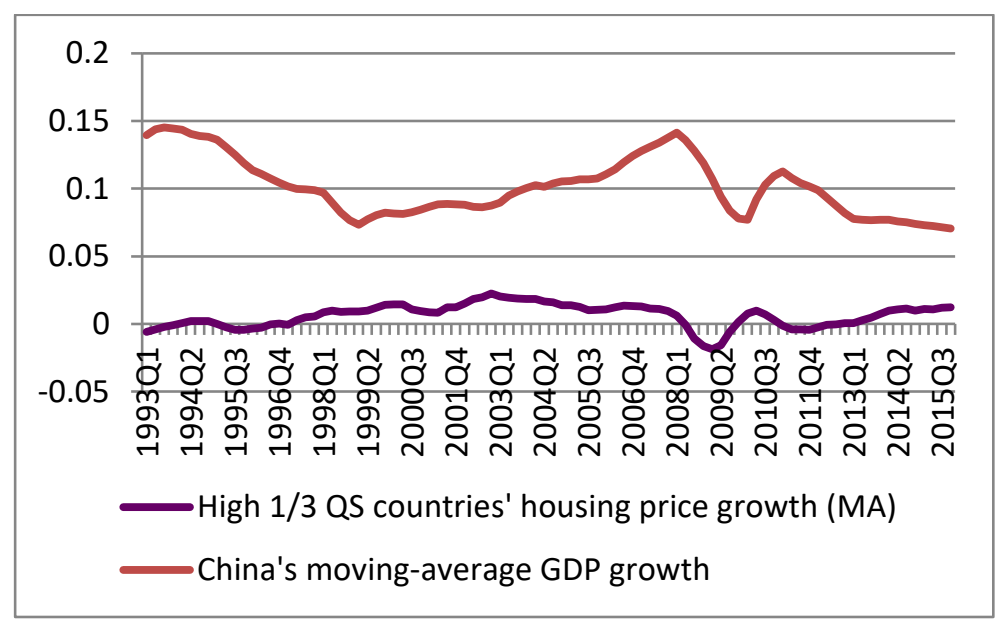

Figure 2B. China's wealth growth and English countries' housing price growth

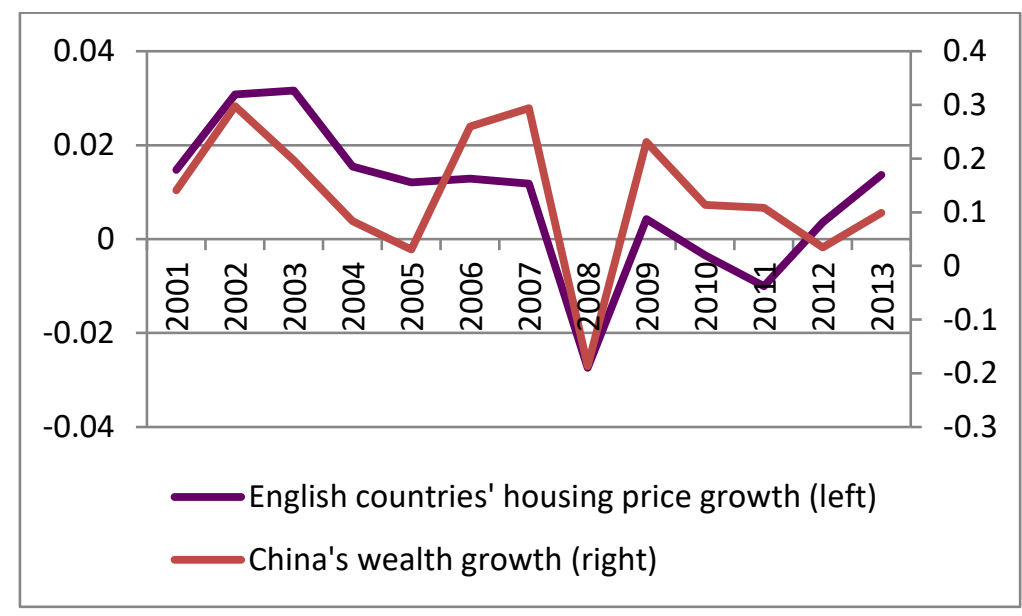

Figure 2D. China's wealth growth and high-QS countries' housing price growth

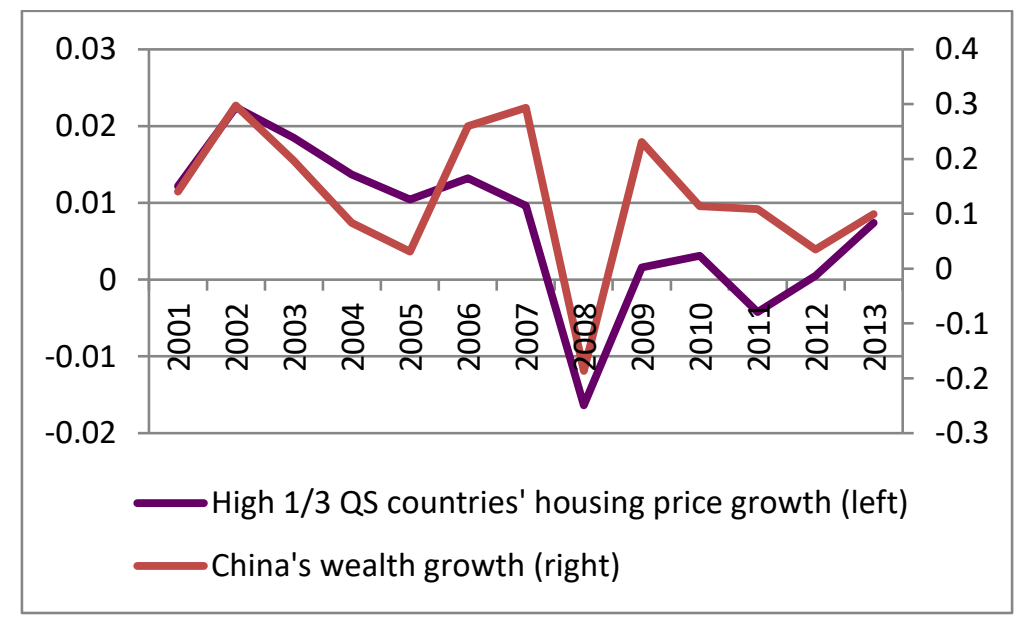


Table 3. China's Past GDP Growth and the Housing Price Growth of Other Markets around the World

The dependent variable is housing price growth. The variable $C$ takes a value of one for observations since 2008 Q1 and zero otherwise. The Appendix defines the other variables. Country fixed effects are included. Robust standard errors in parentheses are based on country and time clustering. $* * *, * *$, and $*$ indicate $1 \%, 5 \%$, and $10 \%$ significance, respectively.

\begin{tabular}{|c|c|c|c|c|c|}
\hline Sample & 93Q1-15Q4 & 93Q1-15Q4 & 96Q1-15Q4 & 81Q1-15Q4 & 93Q1-15Q4 \\
\hline & $(1)$ & $(2)$ & (3) & $(4)$ & (5) \\
\hline \multirow[t]{2}{*}{ cn_pastGDPgrowth } & $-0.074 * * *$ & $-0.077 * * *$ & $-0.080 * *$ & $-0.028 *$ & $-0.076 * *$ \\
\hline & $(0.021)$ & $(0.023)$ & $(0.029)$ & $(0.015)$ & $(0.030)$ \\
\hline \multirow[t]{2}{*}{ loc_pastGDPgrowth } & & $0.326^{* * *}$ & $0.436 * * *$ & $0.248^{* *}$ & 0.108 \\
\hline & & $(0.091)$ & (0.119) & $(0.093)$ & (0.119) \\
\hline \multirow[t]{2}{*}{ wd_pastGDPgrowth } & & $-0.440 * *$ & $-0.376 * *$ & $-0.405^{* *}$ & -0.299 \\
\hline & & $(0.158)$ & $(0.167)$ & $(0.160)$ & $(0.271)$ \\
\hline \multirow[t]{2}{*}{ HousingPriceGrowth(t-1) } & $0.546 * * *$ & $0.556 * * *$ & $0.499 * * *$ & $0.609 * * *$ & $0.516 * * *$ \\
\hline & $(0.054)$ & $(0.046)$ & $(0.070)$ & $(0.042)$ & $(0.060)$ \\
\hline \multirow[t]{2}{*}{ DisposableIncomeGrowth } & $0.338 * * *$ & $0.315^{* * *}$ & $0.241 * *$ & $0.322 * * *$ & $0.238 * * *$ \\
\hline & $(0.064)$ & $(0.069)$ & $(0.091)$ & $(0.061)$ & $(0.081)$ \\
\hline \multirow[t]{2}{*}{ DisposableIncomeGrowth(t-1) } & -0.077 & & & & \\
\hline & $(0.061)$ & & & & \\
\hline \multirow[t]{2}{*}{ interestg } & & & -0.001 & & \\
\hline & & & $(0.002)$ & & \\
\hline \multirow[t]{2}{*}{ rentg } & & & $-0.060^{*}$ & & \\
\hline & & & $(0.032)$ & & \\
\hline \multirow[t]{2}{*}{ urateg } & & & -0.006 & & \\
\hline & & & $(0.010)$ & & \\
\hline \multirow[t]{2}{*}{ permitg } & & & $0.016 * *$ & & \\
\hline & & & $(0.006)$ & & \\
\hline \multirow[t]{2}{*}{ constrg } & & & 0.014 & & \\
\hline & & & $(0.008)$ & & \\
\hline \multirow[t]{2}{*}{$c c g$} & & & $0.115^{* * *}$ & & \\
\hline & & & $(0.030)$ & & \\
\hline \multirow[t]{2}{*}{ exg } & & & $-0.020 * *$ & & \\
\hline & & & $(0.009)$ & & \\
\hline \multirow[t]{2}{*}{ debtg } & & & $0.076 * * *$ & & \\
\hline & & & $(0.020)$ & & \\
\hline \multirow[t]{2}{*}{$C^{*}$ HousingPriceGrowth $(t-1)$} & & & & & 0.004 \\
\hline & & & & & $(0.054)$ \\
\hline \multirow[t]{2}{*}{$C^{*}$ DisposablelncomeGrowth } & & & & & 0.179 \\
\hline & & & & & $(0.118)$ \\
\hline \multirow[t]{2}{*}{$C^{*} c n \_p a s t G D P g r o w t h$} & & & & & $-0.084^{*}$ \\
\hline & & & & & $(0.046)$ \\
\hline \multirow[t]{2}{*}{ C*loc_pastGDPgrowth } & & & & & $0.341^{*}$ \\
\hline & & & & & $(0.176)$ \\
\hline \multirow[t]{2}{*}{$C^{*} w d \_p a s t G D P g r o w t h$} & & & & & -0.383 \\
\hline & & & & & $(0.307)$ \\
\hline \multirow[t]{2}{*}{ C } & & & & & 0.004 \\
\hline & & & & & $(0.005)$ \\
\hline Observations & 2,116 & 1,919 & 1,133 & 2,089 & 1,919 \\
\hline Adjusted R-squared & 0.400 & 0.456 & 0.563 & 0.494 & 0.473 \\
\hline
\end{tabular}


Table 4. Chinese, American, British, and Combined Past GDP Growth and Housing Price Growth around the World

We run the following regressions at the individual country level:
\[ h p g_{\mathrm{t}}=\alpha+\boldsymbol{\beta}^{*} \text { China/US/UK/Combined past GDP growth } h_{\mathrm{t}}+\lambda \text { Controls }_{\mathrm{t}}+\mathrm{e}_{\mathrm{t}} \]

where combined past GDP growth is the growth of the sum of the GDP of France, Germany, and the United Kingdom, with weights based on GDP purchasing power parity. The Appendix defines the variables. This table reports the sign of $\beta$, the estimated coefficient of the past GDP growth in the baseline regressions of the housing price growth of individual countries. $* * *, * *, *$, and \# indicate $1 \%, 5 \%, 10 \%$, and one-sided $10 \%$ significance, respectively.

\begin{tabular}{|c|c|c|c|c|}
\hline pastGDPgrowth: & China & US & UK & Combined \\
\hline Aggregate & $-* * *$ & + & + & $+*$ \\
\hline Australia & $-*$ & - & - & - \\
\hline Belgium & + & - & - & + \\
\hline Canada & $-\#$ & - & + & + \\
\hline Croatia & - & - & $-\#$ & - \\
\hline Denmark & + & $+* *$ & $+\#$ & $+^{*}$ \\
\hline Finland & - & - & - & - \\
\hline France & $-*$ & + & + & \\
\hline Germany & - & - & - & \\
\hline Ireland & $-*$ & + & + & + \\
\hline Israel & + & $-* * *$ & $-* * *$ & $-* * *$ \\
\hline Italy & - & + & + & $+* *$ \\
\hline Japan & + & + & + & + \\
\hline Luxembourg & $-* * *$ & $+^{*}$ & $+* *$ & $+\#$ \\
\hline Netherlands & $-* *$ & + & $+*$ & $+^{*}$ \\
\hline New Zealand & - & $-\#$ & $-\#$ & - \\
\hline Norway & - & $+\#$ & + & + \\
\hline South Africa & $-* *$ & $-* *$ & + & + \\
\hline South Korea & $-*$ & - & + & + \\
\hline Spain & - & - & + & + \\
\hline Sweden & $-*$ & $+\#$ & + & $+\#$ \\
\hline Switzerland & - & $-\#$ & $-\#$ & $-*$ \\
\hline United Kingdom & $-* * *$ & - & & \\
\hline United States & $-* * *$ & & + & $+\#$ \\
\hline Negative proportion & $19 / 23$ & $13 / 22$ & $8 / 22$ & $6 / 20$ \\
\hline Significantly negative proportion ( $1 \%, 5 \%$, or $10 \%)$ & $10 / 23$ & $2 / 22$ & $1 / 22$ & $2 / 20$ \\
\hline
\end{tabular}


Table 5. China's Change in Saving/Wealth Growth and the Housing Price Growth of Other Markets around the World

The dependent variable is housing price growth. The variable d_cnSaving*Gini is the first difference of the interaction of cnSaving and Gini; g_cnWealth*Gini is the difference in the natural log of the values of the interaction between cnWealth and Gini; g_cnWealth per adult*Gini is the difference in the natural log of the values of the interaction between cnWealth per adult and Gini. The Appendix defines the other variables. Country fixed effects are included. Robust standard errors in parentheses are based on country and time clustering. ${ }^{* * *}, * *, *$, and $\#$ indicate $1 \%, 5 \%, 10 \%$, and one-sided $10 \%$ significance, respectively.

\begin{tabular}{|c|c|c|c|}
\hline & (1) & (2) & (3) \\
\hline d_cnSaving*Gini & $\begin{array}{c}0.213^{* * *} \\
(0.049)\end{array}$ & & \\
\hline g_cnWealth*Gini & & $\begin{array}{c}0.016 * * * \\
(0.006)\end{array}$ & \\
\hline g_cnWealth per adult* Gini & & & $\begin{array}{c}0.016 * * * \\
(0.006)\end{array}$ \\
\hline cn_pastGDPgrowth & $\begin{array}{c}-0.092 * * * \\
(0.026)\end{array}$ & $\begin{array}{c}-0.109 * * * \\
(0.037)\end{array}$ & $\begin{array}{c}-0.107 * * * \\
(0.037)\end{array}$ \\
\hline loc_pastGDPgrowth & $\begin{array}{c}0.321^{* * *} \\
(0.092)\end{array}$ & $\begin{array}{c}0.352^{* * *} \\
(0.070)\end{array}$ & $\begin{array}{c}0.352^{* * *} \\
(0.070)\end{array}$ \\
\hline wd_pastGDPgrowth & $\begin{array}{c}-0.272 \# \\
(0.176)\end{array}$ & $\begin{array}{c}-0.244 \# \\
(0.145)\end{array}$ & $\begin{array}{l}-0.249 * \\
(0.144)\end{array}$ \\
\hline HousingPriceGrowth(t-1) & $\begin{array}{c}0.548^{* * *} \\
(0.046)\end{array}$ & $\begin{array}{c}0.574 * * * \\
(0.050)\end{array}$ & $\begin{array}{c}0.574^{* * *} \\
(0.050)\end{array}$ \\
\hline DisposableIncomeGrowth & $\begin{array}{c}0.310 * * * \\
(0.076)\end{array}$ & $\begin{array}{c}0.305^{* * *} \\
(0.072) \\
\end{array}$ & $\begin{array}{c}0.305 * * * \\
(0.072)\end{array}$ \\
\hline Observations & 1,743 & 1,170 & 1,170 \\
\hline Adjusted R-squared & 0.471 & 0.512 & 0.512 \\
\hline
\end{tabular}


Table 6. China's Risk and Housing Price Growth around the World The dependent variable is housing price growth. The variable d_cnSaving*Gini is the first difference of the interaction of cnSaving and Gini. The Appendix defines the other variables. Country fixed effects are included. Robust standard errors in parentheses are based on country and time clustering. ${ }^{* *}, * *, *$, and \# indicate $1 \%, 5 \%, 10 \%$, and one-sided $10 \%$ significance, respectively.

\begin{tabular}{|c|c|c|}
\hline & (1) & (2) \\
\hline \multirow[t]{2}{*}{ cn_PoliticalRiskRating } & $0.061^{* *}$ & 0.024 \\
\hline & $(0.022)$ & $(0.025)$ \\
\hline \multirow[t]{2}{*}{ cn_FinancialRiskRating } & 0.010 & 0.008 \\
\hline & $(0.023)$ & $(0.025)$ \\
\hline \multirow[t]{2}{*}{ cn_EconomicRiskRating } & $-0.056 * *$ & $-0.070 * * *$ \\
\hline & $(0.021)$ & $(0.021)$ \\
\hline \multirow[t]{2}{*}{ loc_PoliticalRiskRating } & 0.006 & 0.011 \\
\hline & $(0.014)$ & $(0.015)$ \\
\hline \multirow[t]{2}{*}{ loc_FinancialRiskRating } & $0.030^{*}$ & $0.028^{*}$ \\
\hline & $(0.015)$ & $(0.016)$ \\
\hline \multirow[t]{2}{*}{ loc_EconomicRiskRating } & $0.069 * * *$ & $0.071 * * *$ \\
\hline & $(0.022)$ & $(0.022)$ \\
\hline \multirow[t]{2}{*}{ wd_PoliticalRiskRating } & 0.020 & -0.036 \\
\hline & $(0.032)$ & $(0.034)$ \\
\hline \multirow[t]{2}{*}{ wd_FinancialRiskRating } & $0.068 \#$ & $0.141^{* *}$ \\
\hline & $(0.051)$ & $(0.056)$ \\
\hline \multirow{2}{*}{ wd_EconomicRiskRating } & 0.001 & 0.060 \\
\hline & $(0.056)$ & $(0.053)$ \\
\hline \multirow{2}{*}{ cn_RiskStoryNum/TotalStoryNum } & & $0.038 * *$ \\
\hline & & $(0.017)$ \\
\hline \multirow[t]{2}{*}{ loc_RiskStoryNum/TotalStoryNum } & & 0.013 \\
\hline & & $(0.013)$ \\
\hline \multirow[t]{2}{*}{ wd_RiskStoryNum/TotalStoryNum } & & $-0.096 * * *$ \\
\hline & & $(0.027)$ \\
\hline \multirow[t]{2}{*}{ d_cnSaving*Gini } & $0.128 * *$ & $0.104 * *$ \\
\hline & $(0.052)$ & $(0.046)$ \\
\hline \multirow[t]{2}{*}{ cn_pastGDPgrowth } & $-0.193 * * *$ & $-0.229 * * *$ \\
\hline & $(0.042)$ & $(0.050)$ \\
\hline \multirow[t]{2}{*}{ loc_pastGDPgrowth } & $0.260 * * *$ & $0.258 * *$ \\
\hline & $(0.089)$ & $(0.094)$ \\
\hline \multirow[t]{2}{*}{ wd_pastGDPgrowth } & $-0.341 \#$ & $-0.505^{* *}$ \\
\hline & $(0.212)$ & $(0.196)$ \\
\hline \multirow[t]{2}{*}{ HousingPriceGrowth $(t-1)$} & $0.495 * * *$ & $0.474 * * *$ \\
\hline & $(0.047)$ & $(0.047)$ \\
\hline \multirow[t]{2}{*}{ DispoablelncomeGrowth } & $0.282 * * *$ & $0.273^{* * *}$ \\
\hline & $(0.073)$ & $(0.072)$ \\
\hline Observations & 1,743 & 1,743 \\
\hline Adjusted R-squared & 0.485 & 0.492 \\
\hline
\end{tabular}


Table 7. Moderating Effects of Correlation with China's Interest Rate on Housing Price Growth around the World

The dependent variable is housing price growth. The variable d_cnSaving*Gini is the first difference of the interaction of cnSaving and Gini. The Appendix defines the other variables. Country fixed effects are included. Robust standard errors in parentheses are based on country and time clustering. ${ }^{* *}, * *, *$, and \# indicate $1 \%, 5 \%, 10 \%$, and one-sided $10 \%$ significance, respectively.

\begin{tabular}{|c|c|c|}
\hline corr used & Measure 1 & Measure 2 \\
\hline & (1) & (2) \\
\hline \multirow[t]{2}{*}{ corr*d_cnSaving*Gini } & $-0.384 * *$ & $-0.245 *$ \\
\hline & $(0.172)$ & $(0.136)$ \\
\hline \multirow[t]{2}{*}{ corr*cn_pastGDPgrowth } & -0.057 & 0.012 \\
\hline & (0.120) & (0.115) \\
\hline \multirow[t]{2}{*}{ corr* $^{*}$ cn_PoliticalRiskRating } & $0.170 * *$ & 0.054 \\
\hline & $(0.082)$ & (0.054) \\
\hline \multirow[t]{2}{*}{ corr $^{*}$ cn_FinancialRiskRating } & $0.105 \#$ & 0.046 \\
\hline & (0.079) & $(0.043)$ \\
\hline \multirow[t]{2}{*}{ corr*cn_EconomicRiskRating } & $-0.170 * *$ & $-0.141 * *$ \\
\hline & $(0.068)$ & $(0.059)$ \\
\hline \multirow[t]{2}{*}{ corr*cn_RiskStoryNum/TotalStoryNum } & -0.029 & -0.023 \\
\hline & $(0.029)$ & $(0.028)$ \\
\hline
\end{tabular}




\begin{tabular}{|c|c|c|}
\hline corr used & Measure 1 & Measure 2 \\
\hline & (1) & (2) \\
\hline \multirow[t]{2}{*}{ d_cnSaving*Gini } & 0.022 & 0.053 \\
\hline & $(0.064)$ & $(0.061)$ \\
\hline \multirow[t]{2}{*}{ cn_pastGDPgrowth } & $-0.232 * * *$ & $-0.224 * * *$ \\
\hline & $(0.055)$ & $(0.054)$ \\
\hline \multirow[t]{2}{*}{ loc_pastGDPgrowth } & $0.253^{* *}$ & $0.258^{* * *}$ \\
\hline & $(0.092)$ & $(0.090)$ \\
\hline \multirow[t]{2}{*}{ wd_pastGDPgrowth } & $-0.517 * *$ & $-0.508^{* *}$ \\
\hline & (0.199) & (0.199) \\
\hline \multirow[t]{2}{*}{ cn_PoliticalRiskRating } & $0.049^{*}$ & 0.032 \\
\hline & $(0.028)$ & $(0.025)$ \\
\hline \multirow[t]{2}{*}{ cn_FinancialRiskRating } & 0.029 & 0.018 \\
\hline & $(0.031)$ & $(0.026)$ \\
\hline \multirow[t]{2}{*}{ cn_EconomicRiskRating } & $-0.104 * * *$ & $-0.101 * * *$ \\
\hline & $(0.021)$ & $(0.020)$ \\
\hline \multirow[t]{2}{*}{ loc_PoliticalRiskRating } & 0.015 & 0.015 \\
\hline & $(0.016)$ & $(0.016)$ \\
\hline \multirow[t]{2}{*}{ loc_FinancialRiskRating } & $0.028 \#$ & $0.028^{*}$ \\
\hline & $(0.017)$ & $(0.016)$ \\
\hline \multirow[t]{2}{*}{ loc_EconomicRiskRating } & $0.059 * *$ & $0.065^{* *}$ \\
\hline & $(0.024)$ & $(0.023)$ \\
\hline \multirow[t]{2}{*}{ wd_PoliticalRiskRating } & -0.035 & -0.039 \\
\hline & $(0.036)$ & $(0.036)$ \\
\hline \multirow[t]{2}{*}{ wd_FinancialRiskRating } & $0.130 * *$ & $0.137^{* *}$ \\
\hline & $(0.056)$ & $(0.057)$ \\
\hline \multirow[t]{2}{*}{ wd_EconomicRiskRating } & $0.076 \#$ & 0.069 \\
\hline & $(0.054)$ & $(0.054)$ \\
\hline \multirow[t]{2}{*}{ loc_RiskStoryNum/TotalStoryNum } & 0.007 & 0.010 \\
\hline & $(0.015)$ & $(0.014)$ \\
\hline \multirow[t]{2}{*}{ cn_RiskStoryNum/TotalStoryNum } & $0.032 *$ & $0.034^{*}$ \\
\hline & $(0.018)$ & $(0.019)$ \\
\hline \multirow[t]{2}{*}{ wd_RiskStoryNum/TotalStoryNum } & $-0.093 * * *$ & $-0.096 * * *$ \\
\hline & $(0.028)$ & $(0.028)$ \\
\hline \multirow[t]{2}{*}{ HousingPriceGrowth(t-1) } & $0.464 * * *$ & $0.468 * * *$ \\
\hline & $(0.047)$ & $(0.047)$ \\
\hline \multirow[t]{2}{*}{ DisposablelncomeGrowth } & $0.268 * * *$ & $0.270 * * *$ \\
\hline & $(0.071)$ & $(0.072)$ \\
\hline Observations & 1,743 & 1,743 \\
\hline Adjusted R-squared & 0.495 & 0.492 \\
\hline
\end{tabular}


Table 8. Incremental Chinese Effects on Housing Price Growth for English Countries over Non-English Countries

\begin{tabular}{|c|c|c|}
\hline \multicolumn{3}{|c|}{$\begin{array}{l}\text { The dependent variable is housing price growth. The variable } \\
\text { d_cnSaving*Gini is the first difference of the interaction of cnSaving and } \\
\text { Gini. The Appendix defines the other variables. Country fixed effects are } \\
\text { included. Robust standard errors in parentheses are based on country and } \\
\text { time clustering. } * * *, * *, * \text {, and \# indicate } 1 \%, 5 \%, 10 \% \text {, and one-sided } 10 \% \\
\text { significance, respectively. }\end{array}$} \\
\hline Eng measure & $\begin{array}{c}\text { Primary } \\
\text { language }\end{array}$ & $\begin{array}{c}\text { De } \\
\text { facto official } \\
\text { and primary } \\
\text { language }\end{array}$ \\
\hline & (1) & (2) \\
\hline Eng*d_cnSaving*Gini & $\begin{array}{c}0.161^{* *} \\
(0.066)\end{array}$ & $\begin{array}{c}0.196 * * * \\
(0.069)\end{array}$ \\
\hline Eng*cn_pastGDPgrowth & $\begin{array}{c}-0.126^{* *} \\
(0.060)\end{array}$ & $\begin{array}{l}-0.116^{*} \\
(0.064)\end{array}$ \\
\hline Eng*cn_PoliticalRiskRating & $\begin{array}{c}0.022 \\
(0.025)\end{array}$ & $\begin{array}{l}-0.002 \\
(0.027)\end{array}$ \\
\hline Eng*cn_FinancialRiskRating & $\begin{array}{c}0.002 \\
(0.035)\end{array}$ & $\begin{array}{l}-0.019 \\
(0.032)\end{array}$ \\
\hline Eng*cn_EconomicRiskRating & $\begin{array}{l}-0.026 \\
(0.042)\end{array}$ & $\begin{array}{c}-0.012 \\
(0.042)\end{array}$ \\
\hline Eng*cn_RiskStoryNum/TotalStoryNum & $\begin{array}{l}-0.017 \\
(0.021)\end{array}$ & $\begin{array}{l}-0.012 \\
(0.024)\end{array}$ \\
\hline d_cnSaving ${ }^{*}$ Gini & $\begin{array}{l}-0.028 \\
(0.077)\end{array}$ & $\begin{array}{l}-0.018 \\
(0.075)\end{array}$ \\
\hline cn_pastGDPgrowth & $\begin{array}{c}-0.197 * * * \\
(0.053)\end{array}$ & $\begin{array}{c}-0.213^{* * *} \\
(0.057)\end{array}$ \\
\hline loc_pastGDPgrowth & $\begin{array}{c}0.222^{* *} \\
(0.093)\end{array}$ & $\begin{array}{c}0.232 * * \\
(0.093)\end{array}$ \\
\hline wd_pastGDPgrowth & $\begin{array}{c}-0.486 * * \\
(0.199)\end{array}$ & $\begin{array}{c}-0.497^{* *} \\
(0.196)\end{array}$ \\
\hline
\end{tabular}




\begin{tabular}{|c|c|c|}
\hline \multirow[t]{2}{*}{ Eng measure } & $\begin{array}{l}\text { Primary } \\
\text { language }\end{array}$ & $\begin{array}{c}\text { De } \\
\text { facto official } \\
\text { and primary } \\
\text { language }\end{array}$ \\
\hline & (1) & (2) \\
\hline \multirow[t]{2}{*}{ cn_PoliticalRiskRating } & $0.042 \#$ & 0.049\# \\
\hline & $(0.031)$ & $(0.030)$ \\
\hline \multirow[t]{2}{*}{ cn_FinancialRiskRating } & 0.032 & 0.036 \\
\hline & $(0.034)$ & $(0.033)$ \\
\hline \multirow[t]{2}{*}{ cn_EconomicRiskRating } & $-0.099 * * *$ & $-0.104^{* * *}$ \\
\hline & $(0.026)$ & $(0.024)$ \\
\hline \multirow[t]{2}{*}{ loc_PoliticalRiskRating } & 0.016 & 0.013 \\
\hline & $(0.017)$ & $(0.016)$ \\
\hline \multirow[t]{2}{*}{ loc_FinancialRiskRating } & $0.033^{*}$ & $0.033^{*}$ \\
\hline & $(0.019)$ & $(0.020)$ \\
\hline \multirow[t]{2}{*}{ loc_EconomicRiskRating } & $0.052 * *$ & $0.055^{* *}$ \\
\hline & $(0.024)$ & $(0.026)$ \\
\hline \multirow[t]{2}{*}{ wd_PoliticalRiskRating } & -0.036 & -0.033 \\
\hline & $(0.036)$ & $(0.036)$ \\
\hline \multirow[t]{2}{*}{ wd_FinancialRiskRating } & $0.118^{* *}$ & $0.122^{* *}$ \\
\hline & $(0.058)$ & $(0.059)$ \\
\hline \multirow[t]{2}{*}{ wd_EconomicRiskRating } & $0.090 \#$ & $0.085 \#$ \\
\hline & (0.058) & $(0.058)$ \\
\hline \multirow[t]{2}{*}{ loc_RiskStoryNum/TotalStoryNum } & 0.005 & 0.006 \\
\hline & $(0.015)$ & $(0.016)$ \\
\hline \multirow[t]{2}{*}{ cn_RiskStoryNum/TotalStoryNum } & $0.036 * *$ & $0.034^{*}$ \\
\hline & $(0.018)$ & (0.019) \\
\hline \multirow[t]{2}{*}{ wd_RiskStoryNum/TotalStoryNum } & $-0.093 * * *$ & $-0.093^{* * *}$ \\
\hline & $(0.029)$ & $(0.028)$ \\
\hline \multirow[t]{2}{*}{ corr*d_cnSaving*Gini } & $-0.400 * *$ & $-0.396 * *$ \\
\hline & $(0.174)$ & $(0.171)$ \\
\hline \multirow[t]{2}{*}{ corr*cn_pastGDPgrowth } & -0.049 & -0.057 \\
\hline & $(0.108)$ & $(0.118)$ \\
\hline \multirow[t]{2}{*}{ corr*cn_PoliticalRiskRating } & $0.169 * *$ & $0.170^{* *}$ \\
\hline & $(0.081)$ & $(0.082)$ \\
\hline \multirow[t]{2}{*}{ corr*Cn_FinancialRiskRating } & 0.100 & 0.100 \\
\hline & $(0.080)$ & $(0.081)$ \\
\hline \multirow[t]{2}{*}{ corr*cn_EconomicRiskRating } & $-0.169 * * *$ & $-0.173 * *$ \\
\hline & $(0.066)$ & $(0.068)$ \\
\hline \multirow[t]{2}{*}{ corr*cn_RiskStoryNum/TotalStoryNum } & -0.029 & -0.029 \\
\hline & $(0.030)$ & $(0.030)$ \\
\hline \multirow[t]{2}{*}{ HousingPriceGrowth(t-1) } & $0.461^{* * *}$ & $0.460 * * *$ \\
\hline & $(0.047)$ & $(0.048)$ \\
\hline \multirow[t]{2}{*}{ DisposablelncomeGrowth } & $0.276^{* * *}$ & $0.278 * * *$ \\
\hline & $(0.072)$ & $(0.070)$ \\
\hline Observations & 1,743 & 1,743 \\
\hline Adjusted R-squared & 0.496 & 0.496 \\
\hline
\end{tabular}


Table 9. Modifying Effects of Higher Education on Housing Price Growth around the World

The dependent variable is housing price growth. The variable d_cnSaving*Gini is the first difference of the interaction of cnSaving and Gini. The Appendix defines the other variables. Country fixed effects are included. Robust standard errors in parentheses are based on country and time clustering. ${ }^{* * *}, * *, *$, and \# indicate $1 \%, 5 \%, 10 \%$, and one-sided $10 \%$ significance, respectively.

\begin{tabular}{|c|c|c|}
\hline Edu measure & QS score & $\begin{array}{l}\text { Top student } \\
\text { destinations }\end{array}$ \\
\hline & (1) & (2) \\
\hline \multirow[t]{2}{*}{ Edu*d_cnSaving*Gini } & $-0.328 \#$ & 0.026 \\
\hline & $(0.224)$ & $(0.086)$ \\
\hline \multirow[t]{2}{*}{ Edu*cn_pastGDPgrowth } & 0.201 & 0.059 \\
\hline & $(0.218)$ & $(0.061)$ \\
\hline \multirow[t]{2}{*}{ Edu*cn_PoliticalRiskRating } & -0.065 & $-0.077 * *$ \\
\hline & $(0.130)$ & $(0.034)$ \\
\hline \multirow[t]{2}{*}{ Edu*cn_FinancialRiskRating } & 0.038 & -0.003 \\
\hline & $(0.081)$ & (0.041) \\
\hline \multirow[t]{2}{*}{ Edu*cn_EconomicRiskRating } & $0.160 * *$ & $0.095 * *$ \\
\hline & $(0.075)$ & $(0.047)$ \\
\hline \multirow[t]{2}{*}{ Edu*cn_RiskStoryNum/TotalStoryNum } & 0.056 & 0.008 \\
\hline & $(0.051)$ & $(0.026)$ \\
\hline \multirow[t]{2}{*}{ d_cnSaving*Gini } & 0.176 & -0.033 \\
\hline & $(0.202)$ & $(0.085)$ \\
\hline \multirow{2}{*}{ cn_pastGDPgrowth } & $-0.335^{*}$ & $-0.199 * * *$ \\
\hline & $(0.180)$ & $(0.055)$ \\
\hline \multirow[t]{2}{*}{ loc_pastGDPgrowth } & $0.200 \#$ & $0.230 * * *$ \\
\hline & $(0.123)$ & $(0.084)$ \\
\hline \multirow[t]{2}{*}{ wd_pastGDPgrowth } & $-0.535^{* *}$ & $-0.491 * *$ \\
\hline & $(0.212)$ & $(0.200)$ \\
\hline \multirow[t]{2}{*}{ cn_PoliticalRiskRating } & 0.085 & $0.048 \#$ \\
\hline & $(0.096)$ & $(0.031)$ \\
\hline \multirow[t]{2}{*}{ cn_FinancialRiskRating } & 0.008 & 0.033 \\
\hline & $(0.056)$ & $(0.037)$ \\
\hline \multirow[t]{2}{*}{ cn_EconomicRiskRating } & $-0.216 * * *$ & $-0.112 * * *$ \\
\hline & $(0.060)$ & $(0.030)$ \\
\hline \multirow[t]{2}{*}{ loc_PoliticalRiskRating } & 0.015 & 0.019 \\
\hline & $(0.017)$ & $(0.017)$ \\
\hline \multirow[t]{2}{*}{ loc_FinancialRiskRating } & $0.033 \#$ & $0.032 \#$ \\
\hline & $(0.021)$ & $(0.020)$ \\
\hline \multirow[t]{2}{*}{ loc_EconomicRiskRating } & $0.051 *$ & $0.054 * *$ \\
\hline & $(0.027)$ & $(0.026)$ \\
\hline
\end{tabular}




\begin{tabular}{|c|c|c|}
\hline Edu measure & QS score & $\begin{array}{l}\text { Top student } \\
\text { destinations }\end{array}$ \\
\hline & (1) & $(2)$ \\
\hline \multirow[t]{2}{*}{ wd_PoliticalRiskRating } & -0.036 & -0.040 \\
\hline & $(0.037)$ & $(0.037)$ \\
\hline \multirow[t]{2}{*}{ wd_FinancialRiskRating } & $0.109 *$ & $0.124 * *$ \\
\hline & $(0.063)$ & (0.059) \\
\hline \multirow[t]{2}{*}{ wd_EconomicRiskRating } & $0.101 *$ & $0.085 \#$ \\
\hline & $(0.061)$ & $(0.060)$ \\
\hline \multirow[t]{2}{*}{ loc_RiskStoryNum/TotalStoryNum } & 0.003 & 0.003 \\
\hline & $(0.016)$ & $(0.014)$ \\
\hline \multirow[t]{2}{*}{ cn_RiskStoryNum/TotalStoryNum } & -0.004 & $0.036^{*}$ \\
\hline & $(0.041)$ & $(0.020)$ \\
\hline \multirow[t]{2}{*}{ wd_RiskStoryNum/TotalStoryNum } & $-0.089 * * *$ & $-0.094 * * *$ \\
\hline & $(0.029)$ & $(0.029)$ \\
\hline \multirow[t]{2}{*}{ corr*d_cnSaving*Gini } & $-0.435 * * *$ & $-0.400 * *$ \\
\hline & $(0.145)$ & $(0.172)$ \\
\hline \multirow[t]{2}{*}{ corr*cn_pastGDPgrowth } & -0.036 & -0.029 \\
\hline & $(0.105)$ & $(0.108)$ \\
\hline \multirow[t]{2}{*}{ corr*cn_PoliticalRiskRating } & $0.143^{*}$ & $0.153^{* *}$ \\
\hline & $(0.086)$ & $(0.077)$ \\
\hline \multirow[t]{2}{*}{ corr*cn_FinancialRiskRating } & 0.100 & 0.096 \\
\hline & $(0.092)$ & $(0.080)$ \\
\hline \multirow[t]{2}{*}{ corr*cn_EconomicRiskRating } & $-0.162 * *$ & $-0.159 * * *$ \\
\hline & $(0.072)$ & $(0.051)$ \\
\hline \multirow[t]{2}{*}{ corr*'cn_RiskStoryNum/TotalStoryNum } & -0.028 & -0.031 \\
\hline & $(0.030)$ & $(0.030)$ \\
\hline \multirow[t]{2}{*}{ Eng*d_cnSaving*Gini } & $0.220 * * *$ & $0.151^{* *}$ \\
\hline & $(0.063)$ & $(0.059)$ \\
\hline \multirow[t]{2}{*}{ Eng*cn_pastGDPgrowth } & $-0.147 * * *$ & $-0.149 * *$ \\
\hline & $(0.057)$ & $(0.064)$ \\
\hline \multirow[t]{2}{*}{ Eng*cn_PoliticalRiskRating } & 0.027 & $0.052^{* *}$ \\
\hline & $(0.026)$ & $(0.022)$ \\
\hline \multirow[t]{2}{*}{ Eng*cn_FinancialRiskRating } & -0.010 & 0.002 \\
\hline & (0.039) & $(0.033)$ \\
\hline \multirow[t]{2}{*}{ Eng*Cn_EconomicRiskRating } & -0.045 & $-0.063 *$ \\
\hline & (0.049) & $(0.038)$ \\
\hline \multirow[t]{2}{*}{ Eng*cn_RiskStoryNum/TotalStoryNum } & -0.026 & -0.021 \\
\hline & $(0.020)$ & $(0.020)$ \\
\hline \multirow[t]{2}{*}{ HousingPriceGrowth(t-1) } & $0.481 * * *$ & $0.451 * * *$ \\
\hline & $(0.047)$ & $(0.047)$ \\
\hline \multirow[t]{2}{*}{ DisposablelncomeGrowth } & $0.251^{* * *}$ & $0.282 * * *$ \\
\hline & $(0.071)$ & $(0.075)$ \\
\hline Observations & 1,665 & 1,743 \\
\hline Adjusted R-squared & 0.507 & 0.499 \\
\hline
\end{tabular}

